\title{
Supply shocks in the market for apprenticeship training
}

Citation for published version (APA):

Muehlemann, S., Pfann, G., Pfeifer, H., \& Dietrich, H. (2020). Supply shocks in the market for apprenticeship training. Maastricht University, Graduate School of Business and Economics. GSBE Research Memoranda No. 036 https://doi.org/10.26481/umagsb.2020036

Document status and date:

Published: 21/12/2020

DOI:

10.26481/umagsb.2020036

Document Version:

Publisher's PDF, also known as Version of record

\section{Please check the document version of this publication:}

- A submitted manuscript is the version of the article upon submission and before peer-review. There can be important differences between the submitted version and the official published version of record.

People interested in the research are advised to contact the author for the final version of the publication, or visit the DOI to the publisher's website.

- The final author version and the galley proof are versions of the publication after peer review.

- The final published version features the final layout of the paper including the volume, issue and page numbers.

Link to publication

\footnotetext{
General rights rights.

- You may freely distribute the URL identifying the publication in the public portal. please follow below link for the End User Agreement:

www.umlib.nl/taverne-license

Take down policy

If you believe that this document breaches copyright please contact us at:

repository@maastrichtuniversity.nl

providing details and we will investigate your claim.
}

Copyright and moral rights for the publications made accessible in the public portal are retained by the authors and/or other copyright owners and it is a condition of accessing publications that users recognise and abide by the legal requirements associated with these

- Users may download and print one copy of any publication from the public portal for the purpose of private study or research.

- You may not further distribute the material or use it for any profit-making activity or commercial gain

If the publication is distributed under the terms of Article $25 \mathrm{fa}$ of the Dutch Copyright Act, indicated by the "Taverne" license above, 
Samuel Muehlemann, Gerard Pfann, Harald Pfeifer, Hans Dietrich

Supply Shocks in the Market for Apprenticeship Training

RM/20/036

ISSN: 2666-8807

\section{GSBE}

Maastricht University School of Business and Economics

Graduate School of Business and Economics

\section{P.O Box 616}

NL- 6200 MD Maastricht

The Netherlands 


\title{
Supply Shocks in the Market for Apprenticeship Training *
}

\author{
Samuel Muehlemann, LMU Munich \& IZA Bonn \\ Gerard Pfann, Maastricht University \& IZA Bonn \\ Harald Pfeifer, BIBB \& ROA Maastricht \\ Hans Dietrich, IAB Nuremberg
}

October 2020

\begin{abstract}
We present a model with heterogeneous inputs and constant elasticity of substitution to examine the possible effects of a supply shock in the market for apprenticeship training. The model's predictions are tested using data from a German high school reform that led to a one-time increase in the supply of highly educated apprentices. A difference-in-differences estimation strategy exploits regional variation in the timing of implementation, and an instrumental variable approach identifies the supply shock effects. We find that apprenticeship contracts among individuals with a high school degree increased by $7.8 \%$, while apprentice wages were unaffected by the supply shock. Moreover, we find no evidence of substitution effects, as the number of training contracts among individuals with a lower-level school degree remained unchanged. Our model predicts that such effects may occur when wages are sticky for apprentices with a high level of education relative to their productivity, which signals inefficiencies in the market for apprenticeship training.
\end{abstract}

JEL Classifications:

Keywords:
$\mathrm{I} 21, \mathrm{~J} 20$

Apprenticeship market, labor supply shock, school reform

\footnotetext{
*We are grateful participants at the LISER seminar in Luxembourg, the CVER Seminar at LSE, the BIBB conference on the economics of VET in Siegburg, the IZA Workshop on the Economics of Education in Bonn, the Learning \& Work Seminar at SBE Maastricht, the EALE annual conference, and the Bildungsökonomischer Ausschuss (VfS) annual meeting for helpful comments.
} 


\section{Introduction}

In times of economic crisis and increasing costs of obtaining academic qualifications, a dual vocational system that combines firm-level training with vocational schooling is gaining popularity in many countries. For example, the United Kingdom and the United States recently launched programs to foster dual apprenticeship training tracks for young school leavers. ${ }^{1}$ In addition, owing to the economic downturn following the COVID-19 pandemic, increasing youth unemployment rates are likely to raise policymaker interest in apprenticeship programs that smooth the transition from education to the labor market. Governments expect substantial returns to such investments, most importantly through improving young job seekers' employability, skills, and future careers. ${ }^{2}$

Along with the increasing policy interest in training young people, labor economists are paying more attention to the functioning of the market for apprenticeship training (e.g., Acemoglu and Pischke 1999; Stevens 1999; Blatter et al. 2016; Dustmann and Schönberg 2009; Cavaglia et al. 2020). Despite widespread research on apprenticeship markets, little is known about the effects of supply shocks. However, the supply of apprentices fluctuates frequently because of demographic changes and increasing academization, or in relation to migration flows.

The aim of our study is to shed light on the effect of a positive supply shock on the equilibrium price and quantity in the market for apprenticeship training. To predict the possible outcomes, we first present a simple theoretical model of the market for two types of school graduates (lower secondary school and high school graduates). In competitive training markets and under the assumption that apprentices with different levels of education are substitutes, we expect that a one-time supply shock of high school graduates leads to an increase (decrease) in the number of apprenticeship contracts among apprentices with a high school (lower secondary school)

\footnotetext{
${ }^{1}$ See https://www.dol.gov/newsroom/releases/eta/eta20200218 and http://researchbriefings.files.parliament.uk/documents/SN03052/SN03052.pdf.

${ }^{2}$ See Ryan (2001), and Wolter and Ryan (2011).
} 
degree and a decrease (increase) in the wage for high school (lower secondary school) graduates. However, the assumption of competitive markets may be particularly strong in the context of the German apprenticeship market, as apprentice wages are subject to collective bargaining agreements across a wide range of training occupations, and employer associations and unions are involved in many aspects of apprenticeship training (Dustmann \& Schönberg 2009). To the extent that institutions in Germany have led to sticky wages, theory predicts that a supply shock of highly educated apprentices would be absorbed by training firms if there was excess demand prior to the supply shock. As a result, a positive supply shock would lead to more apprenticeship contracts without negatively affecting wages.

Our empirical identification strategy exploits the effects of a high school reform in Germany that decreased the duration of high school by one year, which resulted in two cohorts graduating in the same year in a particular state. We exploit regional variation regarding the timing of implementation (see Figure A1) to identify supply shock effects on the apprenticeship market. In Germany, the supply of apprentices with a high school degree is quantitatively important, as such applicants constitute a large and increasing minority of all apprentices. We apply difference-in-differences estimation techniques to empirically identify the effects of the school reform on the number of apprenticeship contracts and apprentice wages, and we also employ fixed-effects and an instrumental variables panel regression to identify the association between supply and apprenticeship contracts and wages. ${ }^{3}$

Our results suggest that the one-time supply shock due to the school reform led to a $7.8 \%$ increase in apprenticeship contracts, but we find no significant effects on wages. The effects are robust across different subsamples and identification strategies. Thus, our results are in line

\footnotetext{
${ }^{3}$ Previous studies have analyzed the relationship between school graduates and apprenticeship contracts (e.g., Baldi et al. 2014; Maier and Walden 2014 for Germany; Muehlemann et al. 2009 for Switzerland). However, demographic changes in the number of school graduates are typically small and the number of training contracts adjusts smoothly over time.
} 
with a market that can be characterized by excess demand for highly educated apprentices, a finding that can be explained by sticky wages in the market for apprentices.

Our results have important implications. As firms are unable to adjust wages downwards in the short run, supply shocks will only be absorbed by training firms in the case of excess demand for apprentices with a particular education level. While the high school reform led to an increase in the supply of highly educated apprentices, other types of supply shocks (e.g., due to migration) may lead to an increase in the supply of apprentices with a lower education level. In such a case, the inability of firms to adjust wages would lead to a scenario of excess supply in the apprenticeship market, at least to the extent that firms expect a positive association between productivity and an apprentice's education level.

The remainder of the paper is organized as follows. Section 2 explains the German school and apprenticeship training system and the implementation of the high school reform. Section 3 presents the theoretical model of the market for apprentices, allowing for heterogeneity in apprentices' initial education levels. Section 4 describes the data, while Section 5 elaborates on our identification strategy. Section 6 presents the empirical results and examines the changes in the key indicators that have occurred since the implementation of the policy and the extent to which these changes can be attributed to the policy. Section 7 includes a discussion of our results. Section 8 concludes.

\section{Secondary schooling and the apprenticeship system in Germany}

In the German apprenticeship market, firms decide whether they want to post any vacancies for apprenticeship training, and individuals can in turn apply for advertised training positions. Following a screening and selection process, the firm and apprentice then sign a training contract that specifies the wage, training and working conditions for the entire duration of the apprenticeship program. In principle, wage levels are determined by collective agreements between employers' associations and unions. These collectively bargained agreements usually 
refer to sectors and regions rather than occupations or specific groups of apprentices. For example, apprentice wages in collective agreements rarely differentiate between more experienced apprentices and those with different schooling backgrounds. This means that firms often pay one fixed wage that does not vary at the firm level despite differences in apprentices such as age, education or training occupation. Firms for which the collective agreements are not legally binding may deviate from their wage-setting rules by offering apprentice wages of no less than $20 \%$ below the minimum wage. Thus, such firms can, in principle, adjust wages in response to supply or demand shocks when hiring new apprentices. Signing a contract implies that the firm commits to the provision of training according to occupation-specific and nationally binding training curricula. At the end of the training period, apprentices take a standardized external exam to obtain their skilled worker qualification (Facharbeiter). The system is characterized by a large coverage of occupations across all industries. Clerical occupations, technical and metal producing occupations, and traditional craft occupations are among the most popular apprenticeships. The median duration of an apprenticeship is three years. The 20 most popular training occupations account for approximately half of the 500,000 new apprenticeship contracts in Germany (BIBB, 2017b).

\section{The high school reform}

The high school reform resulted from Germany's commitment to the Bologna Process that aims to ensure the comparability of higher education qualifications across European member states. From 2001, most federal states (Länder) started to implement the school reform by reducing the minimum duration of a high school degree (Abitur) by one year while keeping the curriculum content unaltered. The timing of the reform implementation was decided by each state individually (Figure A1). As a consequence, implementation took place in different years. Figures 1 and 2 show the increases in the number of high school graduates in West Germany and East Germany, respectively. The increasing number of high school graduates is clearly 
visible in many states despite the overall number of graduates decreasing substantially in this period. In addition, the school reform caused the number of graduates to increase sharply at the time when the double cohort graduated in a particular state.

Figure 1: Number of high school graduates 2007-2015, West Germany

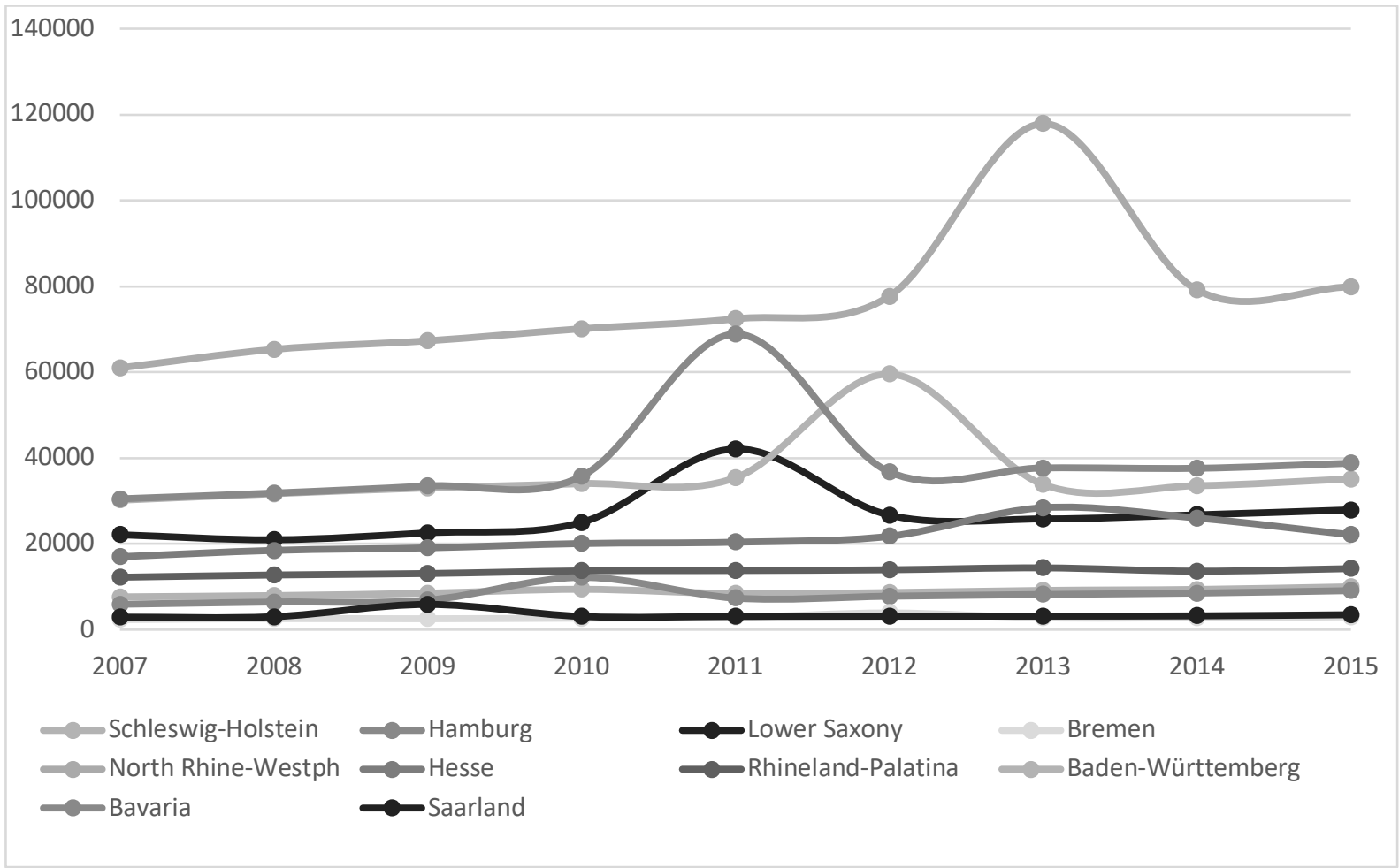

Source: Destatis $(2016,2019)$

Because of the compressed high school curriculum, high school graduates with a shortened schooling duration could have different characteristics compared to those graduates from prior years. However, studies examining competency outcomes (Dahmann 2017) as well as dropout, performance, and motivation (Meyer and Thomsen 2017) find no effects, while other studies find moderate effects for school grades, the probability of grade repetition, and personality traits (Büttner and Thomsen 2015; Dahmann and Anger 2014). In summary, the empirical findings suggest that - if any - the German high school reform had only small effects on the cognitive and noncognitive skills of high school graduates. From a firm's perspective, this implies that 
the characteristics of potential applicants for apprenticeship positions with a high school degree are largely comparable before and after the high school reform.

Figure 2: Number of high school graduates 2007-2015, East Germany

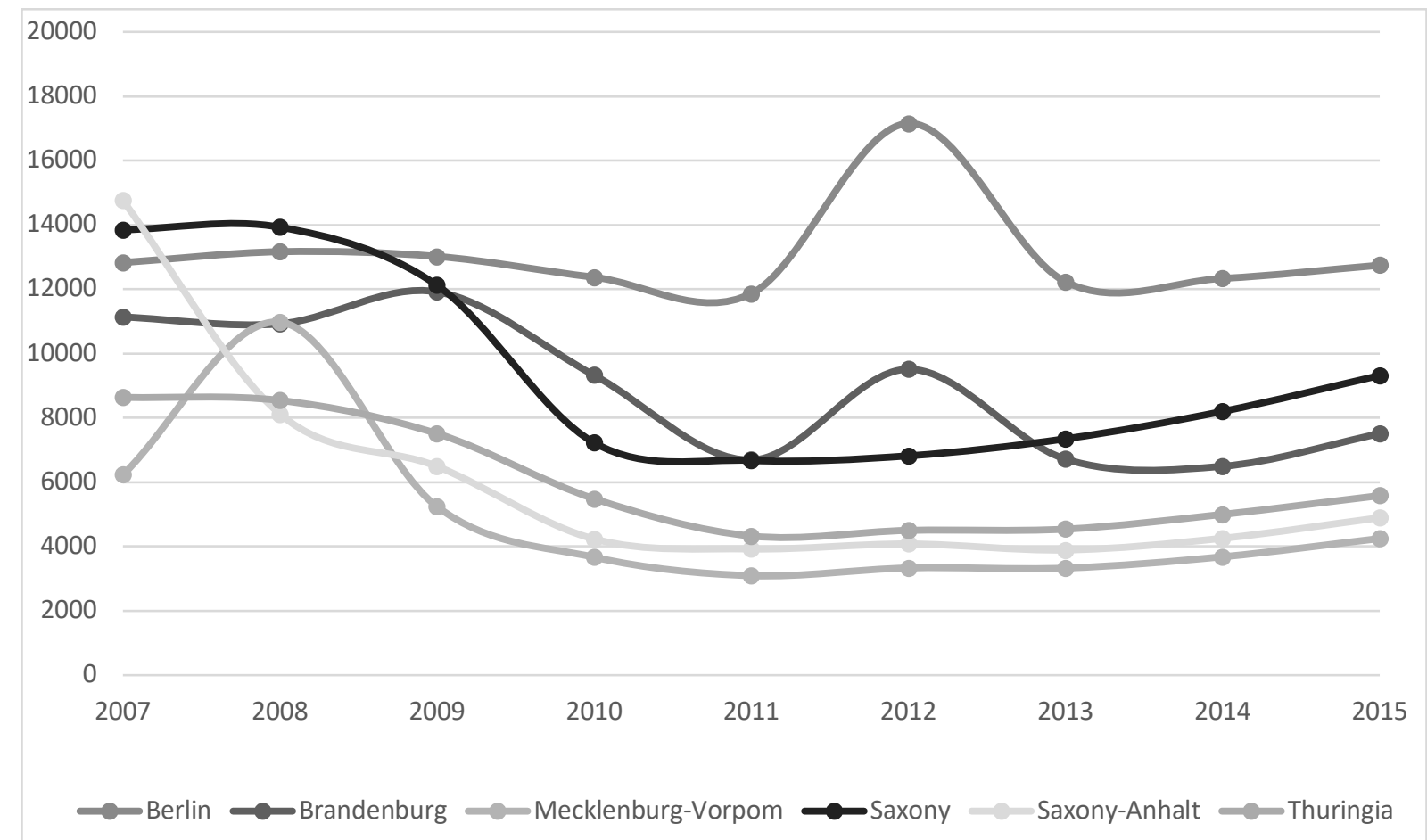

Source: Destatis $(2016,2019)$

In summary, the empirical findings suggest that - if any - the German high school reform had only small effects on the cognitive and noncognitive skills of high school graduates. From a firm's perspective, this implies that the characteristics of potential applicants for apprenticeship positions with a high school degree are largely comparable before and after the high school reform.

\section{Supply shocks in the German apprenticeship market}

Supply shocks in the labor market are usually studied in the literature on immigration. Theoretical models often assume competition, production functions that allow for substitutability between workers, and wages that are fixed in the short run but flexible in the 
long run. ${ }^{4}$ To develop a hypothesis on the possible effects of a one-time supply shock of high school graduates in the apprenticeship market, this section uses a simple static supply and demand framework. ${ }^{5}$ In this model, two types of apprentices compete in the apprenticeship market. ${ }^{6}$ High school apprentices $x_{A}$ require a minimum of 12 to 13 years of education $(A=$ Abitur $=$ high school/gymnasium graduates), whereas apprentices from lower schools $x_{N A}$ require 9 to 10 years of education $(N A=$ No Abitur $=$ lower secondary school graduates $)$. Apprenticeship output $y$ is produced according to a constant elasticity of substitution (CES) technology:

$$
y=\left(\alpha x_{A}^{\rho}+(1-\alpha) x_{N A}^{\rho}\right)^{\frac{1}{\rho}}
$$

where $0<\alpha<1$ is the constant share parameter and $-\infty<\rho \leq 1$ determines the degree of substitutability between $x_{A}$ and $x_{N A}$. In this market, training firms are price takers. The marginal costs of apprenticeship contracting are fixed and differ between the two types, with $w_{A} \geq$ $w_{N A}>0$. Firms minimize their expected training costs subject to $y$ :

$$
\text { Minimize } w_{A} x_{A}+w_{N A} x_{N A}
$$

When short-run output $\bar{y}$ is constant, the respective input demand functions are ${ }^{7}$

$$
\begin{gathered}
x_{A}^{*}\left(w_{A}, w_{N A}, y\right)=\gamma \bar{y}\left(\frac{w_{A}}{\alpha}\right)^{\frac{1}{\rho-1}} \text { and } x_{N A}^{*}\left(w_{A}, w_{N A}, y\right)=\gamma \bar{y}\left(\frac{w_{N A}}{1-\alpha}\right)^{\frac{1}{\rho-1}} \\
\text { with } \gamma=\left(\alpha\left(\frac{w_{A}}{\alpha}\right)^{\frac{\rho}{\rho-1}}+(1-\alpha)\left(\frac{w_{N A}}{1-\alpha}\right)^{\frac{\rho}{\rho-1}}\right)^{-\frac{1}{\rho}} .
\end{gathered}
$$

The firm's cost function is

\footnotetext{
${ }^{4}$ Pischke and Velling (1997) provide an empirical study of supply shocks in the German labor market. They find little to no evidence of substitution effects due to immigration. The more recent study by Dustmann et al. (2017) considers the heterogeneity between skilled and unskilled workers and finds a small decline in local wages and a substantial effect on unemployment due to immigration. This effect, however, is primarily due to firms reducing their input of new labor (diminishing their hiring rate). The authors find no evidence that firms increase their firing rate to make space for new workers. Thus, incumbent workers tend to be shielded from the supply shocks of foreign workers.

${ }^{5}$ See Borjas (2015) and the references therein.

${ }^{6}$ Only a few training occupations have a very high within-occupation share of apprentices with a high school degree (e.g., bank clerk), indicating that applicants with high and low levels of education can indeed be considered substitutes across a wide range of occupations (Figure A4).

${ }^{7}$ See Appendix A for the derivations.
} 


$$
c\left(w_{A}, w_{N A}, y\right)=w_{A} x_{A}^{*}\left(w_{A}, w_{N A}, y\right)+w_{N A} x_{N A}^{*}\left(w_{A}, w_{N A}, y\right)
$$

The marginal and average costs are the same and do not depend on the level of output:

$$
\frac{c\left(w_{A}, w_{N A}, y\right)}{y}=\frac{\partial c\left(w_{A}, w_{N A}, y\right)}{\partial y}=\gamma\left(w_{A}\left(\frac{w_{A}}{\alpha}\right)^{\frac{1}{\rho-1}}+w_{N A}\left(\frac{w_{N A}}{1-\alpha}\right)^{\frac{1}{\rho-1}}\right) .
$$

\section{An upward shock in the supply of $x_{A}$ when the two inputs are substitutes}

We first consider the case most commonly used in (immigration) studies of supply shocks in the labor market. This occurs when factor inputs $x_{A}$ and $x_{N A}$ have a unit elasticity of substitution $(\rho=0)$ and training output can be written as resulting from Cobb-Douglas technology as follows:

$$
y=x_{A}^{\alpha} x_{N A}^{(1-\alpha)}
$$

Under competition, the input shares are independent of the relative costs $w_{A} / w_{N A}$. The marginal productivities for $x_{A}$ and $x_{N A}$ that result from the competitive equilibrium inputs before the introduction of the high school reform can be expressed, respectively, as

$$
w_{A}=\alpha\left(\frac{x_{A}}{x_{N A}}\right)^{\alpha-1} \quad \text { and } \quad w_{N A}=(1-\alpha)\left(\frac{x_{A}}{x_{N A}}\right)^{\alpha} \text {. }
$$

The implications of a positive supply shock in $x_{A}$ on the labor market conditions in the short run are set by the laws of supply and demand. When the supply curve for $x_{N A}$ is upward-sloping and the demand curve is downward-sloping, a positive shock in the supply of $x_{A}$ reduces the equilibrium input of $x_{N A}$ (Borjas 2003). The shift in the supply of higher educated apprentices $x_{A}$ lowers their productivity $\left(\frac{\partial w_{A}}{\partial x_{A}}<0\right)$ and increases that of $x_{N A}\left(\frac{\partial w_{N A}}{\partial x_{A}}>0\right)$.

Let $x_{i}^{t}$ be the total number of apprenticeships, with $t \in\{0 ; 1\} ; t=0$ marks the point in time before the high school reform and $t=1$ marks the point in time after the high school reform; $i$ $\in\{A ; N A\}$. The corresponding supply and demand curves are denoted $S_{i}^{t}$ and $D_{i}^{t}$, respectively. The short-run outcomes are summarized as follows: 


$$
\begin{array}{ccc}
x_{N A}^{1}<x_{N A}^{0} & \text { and } & x_{A}^{1}>x_{A}^{0} \\
w_{N A}^{1}>w_{N A}^{0} & \text { and } & w_{A}^{1}<w_{A}^{0}
\end{array}
$$

The share of high school apprentices $x_{A} /\left(x_{A}+x_{N A}\right)$ increases because short-run demand increases for $x_{A}$ and decreases for $x_{N A}$.

\section{An upward shock in the supply of $x_{A}$ when the two inputs are complements}

Next, we consider the case in which $x_{A}$ and $x_{N A}$ are complementary inputs producing $y$ in fixed proportions. The short-run effect of a positive supply shock in $x_{A}$ with $x_{N A}$ remaining constant is comparable to the case of inelastic demand for $x_{A}$ (see Figure A2 in the appendix). In this case, the short-run effects in the apprenticeship market can be summarized as

$$
\begin{gathered}
x_{N A}^{1}=x_{N A}^{0} \text { and } x_{A}^{1}=x_{A}^{0}, \\
w_{N A}^{1}=w_{N A}^{0} \text { and } \quad w_{A}^{1}<w_{A}^{0} .
\end{gathered}
$$

The share of high school apprentices $x_{A} /\left(x_{A}+x_{N A}\right)$ thus remains unchanged. In the short run, the productivity of lower school apprentices $w_{N A}$ is constant, while $w_{A}$ decreases.

\section{What if wages are sticky?}

Several factors may cause wage rigidity. Apart from implicit contracts and efficiency wages, firm-level institutions such as collective bargaining or works councils, which are especially relevant in the contexts of German labor markets, could prevent wage adjustments in response to productivity shocks. A short-run analysis of the case for wage rigidity is particularly interesting because the implementation of the high school reform in different states takes place in one-year periods at different times. The marginal productivity of high school apprentices is likely to exceed that of lower secondary school apprentices. Moreover, because apprentices from the pre-reform cohort are one year older at the time of graduation, the marginal productivity of the reform cohort may be lower. This would imply that

$$
w_{N A}<w_{A}^{1} \leq w_{A}^{0} .
$$


When wages are fixed, ceteris paribus, demand for high school apprentices $x_{A}$ falls relative to demand for lower school apprentices $x_{N A}$ because $w_{A}^{0}=w_{A}^{1}$. Hence, $w_{A}^{1}$ is now "too high," while $w_{N A}$ remains constant. Whether this effect is observed depends on the fixed wage level for high school apprentices, $w_{A}^{*}$.

Figure A3 in the appendix illustrates the situation of institutionally restricted apprentice wages. No initial adjustment to the equilibrium level $w_{A}^{*}$ occurs since demand for highly educated apprentices is too high and $w_{A}^{*}$ is too low. Wages are set at a level that is too low to clear the market. Given wage $w_{A}^{*}$, demand for high school apprentices exceeds supply. The market is characterized by excess demand. When a supply shock occurs, the result is that the supply of highly educated apprentices is absorbed entirely by firms such that

$$
x_{N A}^{1}=x_{N A}^{0} \text { and } x_{A}^{1}>x_{A}^{0} .
$$

Thus, for the scenarios of substitutes, complements, and wage rigidity, we can formulate the following relationships between employment and wages:

\begin{tabular}{|c|c|c|}
\hline $\boldsymbol{x}_{\boldsymbol{A}}, \boldsymbol{x}_{\boldsymbol{N} A}$ substitutes & $\boldsymbol{x}_{\boldsymbol{A}}, \boldsymbol{x}_{\boldsymbol{N}}$ complements & wage rigidity \\
\hline$x_{N A}^{1}<x_{N A}^{0} ; x_{A}^{1}>x_{A}^{0}$ & $x_{N A}^{1}=x_{N A}^{0} ; x_{A}^{1}=x_{A}^{0}$ & $x_{N A}^{1}=x_{N A}^{0} ; x_{A}^{1}>x_{A}^{0}$ \\
\hline$w_{N A}^{1}>w_{N A}^{0} ; w_{A}^{1}<w_{A}^{0}$ & $w_{N A}^{1}=w_{N A}^{0} ; w_{A}^{1}<w_{A}^{0}$ & $w_{N A}^{1}=w_{N A}^{0} ; w_{A}^{1}=w_{A}^{0}$ \\
\hline
\end{tabular}

\section{Data and variable construction}

More than two-thirds of German youth graduate from lower secondary schools. ${ }^{8}$ The dominant choice of most individuals is to apply for an apprenticeship in the "dual system", which

\footnotetext{
${ }^{8}$ After primary school, usually at the age of 10, students continue their education in one of three secondary school types based on their performance in the primary schools. While lower secondary tracks (Hauptschule and Realschule) require another five to six years of school attendance after the first four years of elementary school, upper secondary high school entrants study another eight to nine years. The school types vary not only in terms of the number of schooling years but also in terms of the level of expected learning abilities (see also Wößmann 2016).
} 
combines in-company training with part-time education in a vocational school. The typical starting age for an apprenticeship is between 16 and 20 years old. Overall, more than 500,000 new apprenticeship contracts are signed each year, and with most apprenticeships lasting three years, approximately 1.5 million young adults are enrolled in an apprenticeship at any given point in time (BIBB 2017a).

Figure 3: High school and lower secondary school degree applicants 2007 to 2015

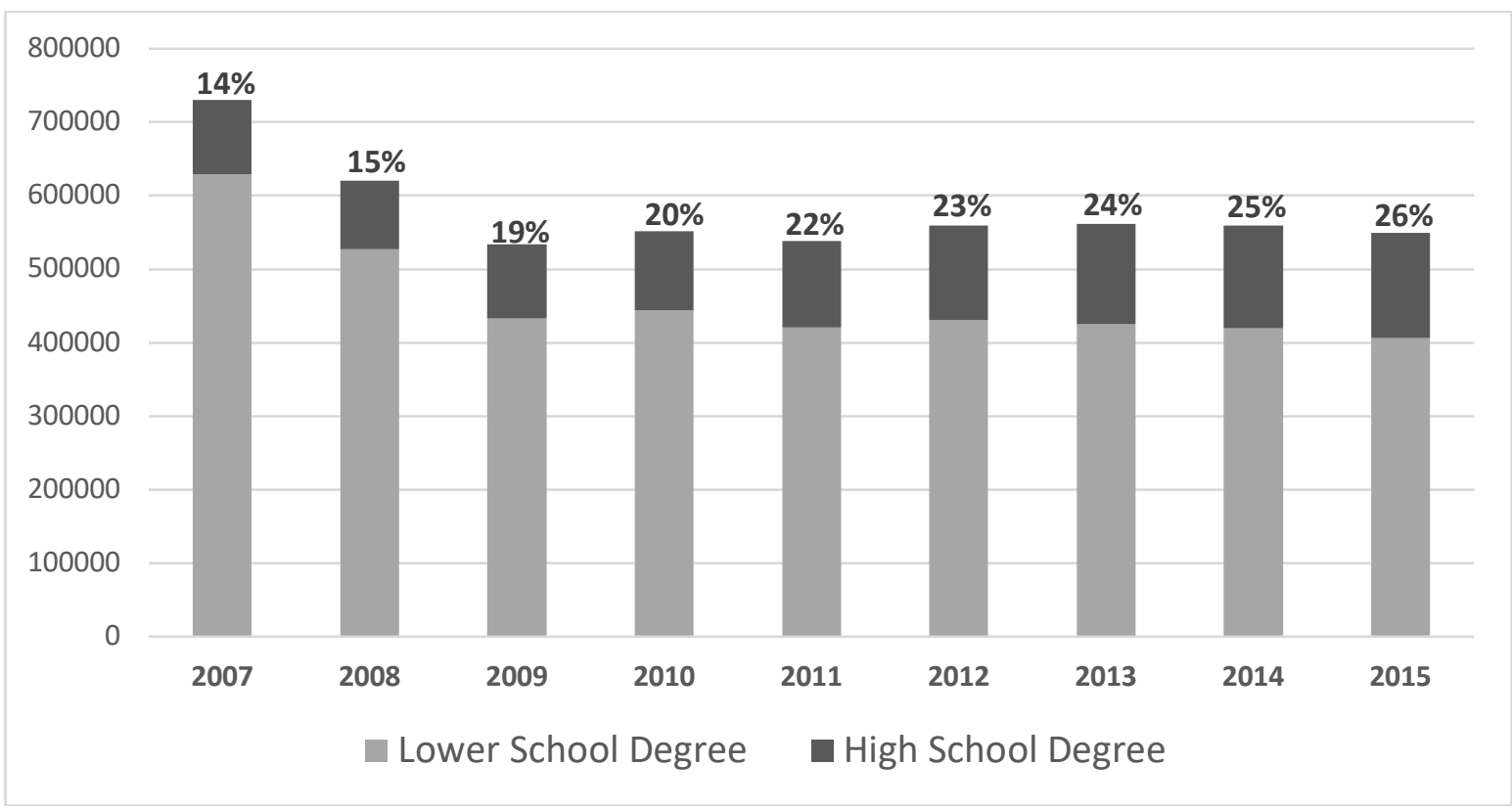

Source: BIBB Data Reports 2008-2016 (https://www.bibb.de/datenreport/). Lower secondary school degree contains both graduates of lower secondary schools and those without a secondary degree.

Although they have access to a university education, a significant share of high school graduates apply for an apprenticeship (BIBB 2017a). Figure 3 shows the number of high school applicants relative to the number of applicants with lower secondary school degrees between 2007 and 2017. The share of applicants with a high school degree increased from approximately $14 \%$ in 2007 to $27 \%$ in 2017 . This indicates that in comparison to other school graduates, high school graduates have become more prevalent in the apprenticeship market in recent years.

The data source for our empirical analysis is the universe of all new yearly apprenticeship contracts provided by the Federal Statistical Office. The data include training characteristics (e.g., of the contract holder) and regional and occupation-specific information. We construct an 
occupation-level panel data set that includes the number of new contracts in a given occupation, state and year. We end up with 321 apprenticeship occupations for the 16 federal states over the period 2007 to 2015 .

Second, our measure of the potential supply of apprentices is the number of graduates from high schools (having obtained upper secondary degrees) and of graduates from lower secondary schools. Statistics on the yearly number of school graduates are available from the Federal Statistical Office (Destatis 2016, 2019). Table 1 shows the growth rate of apprenticeship contracts per state from 2008 to 2015 . Although it is not possible to quantify reform effects based on the descriptive information in the table, some states indeed show a clear increase in the growth rate of apprenticeship contracts with high school graduates in the year when a particular state was affected by the high school reform. Bavaria and Lower Saxony, for example, show an increase in apprenticeship contracts among individuals who have obtained a high school degree of almost $30 \%$ in the year when the reform affected high school graduation rates. However, some smaller states were likely affected by reform-induced graduation rates in neighboring states, as high school graduates may apply for out-of-state apprenticeships. Bremen, a small city-state, is fully surrounded by the much larger state of Lower Saxony. Thus, in the year when the double cohort in Lower Saxony graduated, the number of apprenticeships in Bremen increased sharply because many apprentices employed by firms located in Bremen actually reside in Lower Saxony. However, even in the year prior to the reform, approximately one-third of all apprentices in Bremen lived in Lower Saxony (Table A1). We can explain this observation by the fact that the population of Lower Saxony is more than ten times larger than that of the city-state of Bremen. To take into account such interrelations between neighboring states, we also analyze subsamples of states affected by the school reform in different years. ${ }^{9}$

\footnotetext{
${ }^{9}$ We drop the state of Hesse from our analysis because double graduation from high school stretched over two years.
} 
However, in general, we find that the vast majority of apprentices live and work in the same state and that the reform did not increase cross-border mobility (Table A1).

Table 1: Growth rate of the number of apprentices with a high school degree (by state), 2008-2015

\begin{tabular}{ccccccccccccccccc}
\hline Year & SH & HH & NI & HB & NW & HE & RP & BW & BY & SL & BE & BB & MV & SN & ST & TH \\
\hline 2008 & $-8 \%$ & $-10 \%$ & $-6 \%$ & $4 \%$ & $2 \%$ & $-1 \%$ & $3 \%$ & $-8 \%$ & $-2 \%$ & $11 \%$ & $-1 \%$ & $3 \%$ & $21 \%$ & $4 \%$ & $-13 \%$ & $-3 \%$ \\
2009 & $10 \%$ & $3 \%$ & $-2 \%$ & $-2 \%$ & $-2 \%$ & $-5 \%$ & $-4 \%$ & $2 \%$ & $-13 \%$ & $1 \%$ & $-5 \%$ & $-3 \%$ & $-10 \%$ & $-5 \%$ & $-7 \%$ & $-9 \%$ \\
2010 & $8 \%$ & $11 \%$ & $7 \%$ & $3 \%$ & $5 \%$ & $7 \%$ & $11 \%$ & $9 \%$ & $12 \%$ & $-5 \%$ & $2 \%$ & $-10 \%$ & $-13 \%$ & $-12 \%$ & $-12 \%$ & $-3 \%$ \\
2011 & $16 \%$ & $6 \%$ & $27 \%$ & $14 \%$ & $8 \%$ & $11 \%$ & $12 \%$ & $19 \%$ & $30 \%$ & $-4 \%$ & $-3 \%$ & $-8 \%$ & $-5 \%$ & $1 \%$ & $-6 \%$ & $-6 \%$ \\
2012 & $-2 \%$ & $-2 \%$ & $-6 \%$ & $-5 \%$ & $3 \%$ & $3 \%$ & $3 \%$ & $11 \%$ & $-3 \%$ & $11 \%$ & $4 \%$ & $-7 \%$ & $-12 \%$ & $-7 \%$ & $-15 \%$ & $-10 \%$ \\
2013 & $1 \%$ & $-2 \%$ & $0 \%$ & $-3 \%$ & $7 \%$ & $0 \%$ & $0 \%$ & $-3 \%$ & $0 \%$ & $-8 \%$ & $-7 \%$ & $-8 \%$ & $-2 \%$ & $-11 \%$ & $-2 \%$ & $-12 \%$ \\
2014 & $6 \%$ & $1 \%$ & $5 \%$ & $-1 \%$ & $-2 \%$ & $2 \%$ & $7 \%$ & $7 \%$ & $8 \%$ & $5 \%$ & $4 \%$ & $-4 \%$ & $0 \%$ & $3 \%$ & $-4 \%$ & $1 \%$ \\
2015 & $12 \%$ & $3 \%$ & $5 \%$ & $0 \%$ & $4 \%$ & $4 \%$ & $7 \%$ & $7 \%$ & $10 \%$ & $4 \%$ & $4 \%$ & $6 \%$ & $5 \%$ & $9 \%$ & $1 \%$ & $3 \%$ \\
\hline
\end{tabular}

Notes: Gray cells indicate the year in which a double cohort graduated from high school due to the reform. $\mathrm{SH}=$ Schleswig-Holstein, HH=Hamburg, NI=Lower Saxony, HB=Bremen, NW=North Rhine-Westphalia, $\mathrm{HE}=$ Hesse, RP=Rhineland-Palatinate, BW=Baden-Württemberg, BY=Bavaria, SL=Saarland, BE=Berlin, $\mathrm{BB}=$ Brandenburg, MV=Mecklenburg-Vorpommern, SN=Saxony, ST=Saxony-Anhalt, TH=Thuringia. Source: Federal Statistical Office contract data.

Finally, we exploit an administrative data set (the 100\% sample of the "integrated labor market biographies") (IEB; see Antoni et al. 2019), which contains information on daily apprentice wages at the three-digit occupation level. This is the only representative data source in Germany that allows us to calculate apprentice wages at the occupation level in a particular state and over time. Table 2 shows the development of daily apprentice wages in German states from 2007 to 2015. On average, apprentices with a high school degree earn 17 to 30 euros per day in their first year of training. Apprentice wages increased strongly over our observation period; however, the level of apprentice pay clearly differed by state. In particular, apprentice wages were substantially lower in East Germany at the beginning of our observation period, although East German apprentice wages caught up over time and reduced the gap with the western states substantially. ${ }^{10}$ While differences in apprentice wages across states can be due to regional heterogeneity in collective bargaining agreements, wages are also related to differences in

\footnotetext{
${ }^{10}$ On average, apprentices with a high school degree earn approximately $12.5 \%$ more than apprentices without a high school degree. This difference is largely due to sorting of high school apprentices into higher paying apprenticeship occupations.
} 
economic activity across states and thus differences in the relative importance of particular training occupations..$^{11}$

Table 2: Average daily wage of new apprentices with a high school degree (in euros, by state), 2007-2015

\begin{tabular}{ccccccccccccccccc}
\hline Year & SH & HH & NI & HB & NW & HE & RP & BW & BY & SL & BE & BB & MV & SN & ST & TH \\
\hline 2007 & 21.3 & 23.4 & 21.5 & 21.2 & 22.2 & 23.5 & 22.1 & 24.6 & 22.9 & 22.0 & 21.8 & 17.6 & 17.3 & 17.6 & 17.6 & 16.9 \\
2008 & 21.8 & 23.8 & 22.1 & 22.2 & 23.1 & 23.9 & 22.9 & 25.3 & 23.5 & 23.2 & 22.2 & 18.8 & 18.3 & 18.7 & 19.2 & 18.1 \\
2009 & 22.0 & 24.0 & 22.6 & 22.0 & 23.4 & 24.3 & 23.4 & 25.6 & 23.7 & 23.0 & 22.5 & 19.7 & 19.6 & 19.4 & 19.9 & 18.3 \\
2010 & 22.5 & 24.2 & 22.8 & 22.9 & 23.6 & 24.3 & 23.6 & 25.3 & 23.9 & 22.8 & 22.1 & 20.2 & 19.5 & 19.8 & 20.6 & 19.2 \\
2011 & 22.5 & 24.5 & 22.8 & 22.7 & 23.6 & 24.7 & 23.0 & 25.2 & 24.2 & 22.9 & 22.1 & 21.0 & 20.2 & 19.5 & 21.5 & 20.3 \\
2012 & 24.0 & 25.7 & 24.6 & 23.9 & 24.7 & 26.8 & 25.1 & 28.6 & 26.0 & 24.8 & 24.6 & 22.5 & 21.7 & 20.7 & 21.8 & 21.8 \\
2013 & 24.3 & 25.6 & 25.5 & 24.8 & 25.3 & 26.8 & 25.2 & 28.2 & 26.2 & 25.2 & 24.5 & 23.4 & 21.9 & 21.9 & 22.7 & 22.7 \\
2014 & 24.9 & 26.2 & 26.0 & 25.5 & 25.9 & 27.4 & 25.7 & 28.7 & 26.6 & 25.5 & 25.4 & 23.8 & 22.9 & 22.4 & 23.7 & 23.6 \\
2015 & 25.5 & 26.9 & 26.5 & 25.6 & 26.4 & 27.8 & 26.3 & 29.1 & 27.5 & 26.0 & 25.8 & 24.2 & 23.6 & 23.2 & 24.4 & 24.5 \\
\hline
\end{tabular}

Notes: Gray cells indicate the year in which a double cohort graduated from high school due to the reform. $\mathrm{SH}=$ Schleswig-Holstein, HH=Hamburg, NI=Lower Saxony, HB=Bremen, NW=North Rhine-Westphalia, $\mathrm{HE}=$ Hesse, $\mathrm{RP}=$ Rhineland-Palatinate, $\mathrm{BW}=$ Baden-Württemberg, $\mathrm{BY}=$ Bavaria, $\mathrm{SL}=$ Saarland, BE=Berlin, $\mathrm{BB}=$ Brandenburg, $\mathrm{MV}=$ Mecklenburg-Vorpommern, $\mathrm{SN}=$ Saxony, $\mathrm{ST}=$ Saxony-Anhalt, $\mathrm{TH}=$ Thuringia. Source: IEB employer-employee linked data.

\section{Identification strategy}

In our first step, we apply difference-in-differences estimation techniques to identify the effect of the high school reform on the number of new apprenticeship contracts and the corresponding wages of new apprentices. Second, to identify whether the relationship between school leavers and apprenticeship contracts differs in a year when the number of graduates was affected by the school reform, we estimate the elasticity of the number of apprenticeship contracts (and apprentice wages) with respect to the number of school leavers with a high school and lower secondary school qualification. Finally, we use an instrumental variable panel regression and exploit the exogenous change in the supply of apprentices that was caused by the high school reform. For each step and each regression, we provide overall results for Germany and separate results for West and East Germany. The reason for doing so is that even more than 30 years

\footnotetext{
${ }^{11}$ The automotive industry, for example, is particularly important in Baden-Württemberg, Bavaria, and Lower Saxony, but much less important in many other states.
} 
after reunification, training and labor markets are still shaped by stark differences between East and West Germany (Schnabel 2016).

\section{Difference-in-differences estimation to identify the effects of the high school reform}

We estimate the following fixed-effects panel model, where we denote the log number of new contracts of apprentices with a high school degree in occupation $o$ in state $s$ in year $t$ as

$$
a_{o s t}^{H S}=\alpha_{o s}+\lambda_{t}^{H S}+\theta^{H S} G 8_{s t}+\gamma_{o}^{H S} t_{o}+\gamma_{s}^{H S} t_{s}+\epsilon_{o s t}^{H S}
$$

where the difference-in-differences estimator is $\theta^{H S}$, as $G 8_{s t}$ is an indicator variable equal to 1 when graduation rates were affected by the school reform in year $t$ in state $s$. Thus, $\theta^{H S}$ is an estimate of the average number of additional apprenticeship contracts signed because of the school reform across all German states. Moreover, $\alpha_{o s}$ controls for the fixed effects for occupation $o$ in state $s$ and accounts for the fact that the baseline shares of apprentices with a

high school degree vary by training occupation and state. The year dummies $\lambda_{t}^{H S}$ control for year-specific effects. The trend variable $t_{o}$ at occupation level $o$ controls for occupationspecific developments over time, and $t_{s}$ controls for developments at the state level. ${ }^{12}$ Thus, we assume that when accounting for all these factors, states other than those in which graduation rates were affected by the reform in a particular year $t$ show comparable development (common trends) in the number of apprenticeship contracts. We also provide robustness checks by analyzing subsamples of neighboring states (e.g., Bavaria and Baden-Wurttemberg). In such states, it may be even more reasonable to assume that both economic development and general interest in the apprenticeship training of individuals and firms are more comparable than for states that differ more in their geographic proximity.

\footnotetext{
12 Jansen et al. (2017) estimate a model similar to this one.
} 
Second, we estimate an identical specification, but with the initial log daily wages of new apprentices as the dependent variable, to identify the potential wage effects of the high school reform $D$ :

$$
w_{o s t}^{H S}=\alpha_{o s}+\lambda_{t}^{H S}+\theta^{H S} D_{s t}+\gamma_{o}^{H S} t_{o}+\gamma_{s}^{H S} t_{s}+\epsilon_{o s t}^{H S}
$$

Again, we assume that the state, occupation, and time fixed effects as well as the trend variables at the state and occupation levels account for the relevant factors that drive apprentice wages, such that any other unobserved factors in year $t$ are not associated with the timing of the school reform. Thus, the difference-in-differences estimator $\theta^{H S}$ measures the effect of the high school reform on apprentice wages. To account for the fact that apprentice wages vary by economic sectors, we also provide robustness checks using subsamples of occupational fields at the 1digit level.

\section{Estimating the elasticity of apprenticeship contracts with respect to school graduates}

While the difference-in-differences estimation yields the direct effect of the high school reform on the number of apprenticeship contracts and wages, we are also interested in analyzing the extent to which the number of high school graduates is associated with the number of apprenticeship contracts for individuals with a high school degree. As shown in Section 4, the share of apprentices with a high school degree has increased substantially in recent years. Thus, we estimate the elasticity of the number of apprenticeship contracts with respect to the number of high school graduates:

$$
a_{o s t}^{H S}=\alpha_{o s}+\lambda_{t}^{H S}+\theta^{H S} \text { graduates }_{s t}+\gamma_{o}^{H S} t_{o}+\gamma_{s}^{H S} t_{s}+\epsilon_{o s t}^{H S},
$$

where graduates $_{\text {st }}$ is defined as the log number of individuals who graduate from high school in year $t$ and state $s$. Moreover, we include the same fixed effects and trend variables as in the difference-in-differences specification above.

Second, we estimate an identical specification, but with the log daily wage of apprentices as the dependent variable: 


$$
w_{o s t}^{H S}=\alpha_{o s}+\lambda_{t}^{H S}+\theta^{H S} \text { graduates }_{s t}+\gamma_{o}^{H S} t_{o}+\gamma_{s}^{H S} t_{s}+\epsilon_{o s t}^{H S} .
$$

\section{Instrumental variable estimation}

Finally, we estimate the association between high school graduates and the number of apprenticeship contracts (and apprentice wages) in the year in which the high school reform led to an increase in high school graduation rates. We use the high school reform as an instrument for the number of graduates, as the reform itself constitutes plausibly exogenous variation in the number of high school graduates. The school reform is a valid instrument to the extent that its implementation date (in period $t-8$ ) is independent of the number of apprenticeship contracts in period $t$. Further, as the school reform was unrelated to any issues in the vocational education and training system, and thus the development of apprenticeship contracts, it constitutes a valid instrument. Moreover, the timing of the implementation can be considered random, as political processes in some states may require more time for reasons unrelated to current developments in the apprenticeship market. Thus, we can interpret the results as a local average treatment effect: we identify the extent to which the number of apprenticeship contracts and apprentice wages are affected by the reform-induced change in the number of high school graduates.

\section{Results}

In this section, we first report our difference-in-differences estimates and then discuss the results from our panel fixed-effects and instrumental variable panel fixed-effects regressions to identify the association between the number of high school graduates and our dependent variables of interest. Finally, we report robustness checks and test for anticipation effects of the high school reform. 


\section{Difference-in-differences estimates}

As expected, the positive supply shock led to an increase in apprenticeship contracts for individuals with a high school degree. For Germany as a whole, the high school reform raised the number of apprenticeship contracts by $7.8 \%$. The effect was somewhat lower in West Germany (7\%) and higher in East Germany (12.3\%), as reported in Table 3. However, the positive supply shock of high school graduates had no effect on the number of apprenticeship contracts among individuals with lower secondary school degrees, as reported in Table 4. Thus, these results are not in line with the predictions of our theoretical model that assumes that apprentices with different education levels were substitutes in the production process.

With regard to apprenticeship wages, we expect a negative effect of the high school reform if markets are competitive. However, our occupation-level panel fixed-effects estimates show no evidence of any negative wage effects due to the high school reform once we account for statelevel trends in apprentice wages (Table 5). Similarly, we find no wage effects from the reform when estimating a panel fixed-effects regression model at the occupational level for the subsample of apprentices without a high school degree once we include a trend variable at the state level (Table 6). ${ }^{13}$

Thus, our results suggest that the institutional setting of the German apprenticeship system prevents firms from adjusting wages downward. The implication of this finding is that there was excess demand for apprentices with a high school degree prior to the reform-induced supply shock. While no formal rules prevent training firms from increasing their wage offers when facing a shortage in supply to the market-clearing level, institutions such as the collective

\footnotetext{
${ }^{13}$ As a robustness check, we also ran a pooled OLS regression based on individual-level administrative data from the Institute for Employment Research (Table A2). We find no evidence of a wage decrease for high school apprentices due to the high school reform, which is in line with our occupation-level panel fixed-effects regressions in Table 6. The point estimates in models 1 and 2 are even positive, although the magnitude of the estimates are (despite their statistical significance) not economically significant. Focusing on apprentices without a high school degree, we find a negative association between wages and the school reform (Table 8, models 4-6), although the effects are mainly driven by individuals in East Germany. However, note that pooled OLS regressions at the individual level cannot take into account effects of high school graduates sorting into training occupations. Therefore, our preferred identification strategy is the use of panel fixed-effects regression models that use aggregated data at the occupation-level within states and over time.
} 
bargaining system or works councils may impose informal constraints on firms to not raise wages above the level specified in the corresponding bargaining agreement and to prevent firms from offering wages that differ by education levels.

Table 3: Effects of the high school reform on the number of apprenticeship contracts among high school graduates

\begin{tabular}{lccccc}
\hline $\ln$ (contracts HS degree) & Model 1 & Model 2 & Model 3 & $\begin{array}{c}\text { West } \\
\text { Germany }\end{array}$ & $\begin{array}{c}\text { East } \\
\text { Germany }\end{array}$ \\
\hline High school reform & $0.114 * * *$ & $0.113 * * *$ & $0.078^{* * *}$ & $0.070 * * *$ & $0.123^{* * *}$ \\
& $(0.012)$ & $(0.011)$ & $(0.012)$ & $(0.013)$ & $(0.030)$ \\
Year dummies & Yes & Yes & Yes & Yes & Yes \\
Occupational trends & No & Yes & Yes & Yes & Yes \\
State-level trends & No & No & Yes & Yes & Yes \\
State-level occupation FE & Yes & Yes & Yes & Yes & Yes \\
Constant & $2.015^{* * *}$ & $1.899 * * *$ & $1.855^{* * *}$ & $1.912^{* * *}$ & $1.782^{* * *}$ \\
& $(0.010)$ & $(0.026)$ & $(0.031)$ & $(0.032)$ & $(0.065)$ \\
\hline Observations & 23470 & 23470 & 23470 & 16237 & 7233 \\
$R^{2}$ & 0.027 & 0.053 & 0.209 & 0.252 & 0.204 \\
\hline
\end{tabular}

Notes: Standard errors are in parentheses. $* * *$ Significant at the $1 \%$ level; $* *$ significant at the $5 \%$ level; * significant at the $10 \%$ level.

Table 4: Effects of the high school reform on the number of apprenticeship contracts among lower secondary school graduates

\begin{tabular}{lccccc}
\hline $\ln ($ contracts LS degree) & Model 1 & Model 2 & Model 3 & $\begin{array}{c}\text { West } \\
\text { Germany }\end{array}$ & $\begin{array}{c}\text { East } \\
\text { Germany }\end{array}$ \\
\hline High school reform & $0.033^{* * *}$ & $0.037 * * *$ & 0.007 & 0.004 & 0.001 \\
& $(0.010)$ & $(0.009)$ & $(0.010)$ & $(0.010)$ & $(0.025)$ \\
Year dummies & Yes & Yes & Yes & Yes & Yes \\
Occupational trends & No & Yes & Yes & Yes & Yes \\
State-level trends & No & No & Yes & Yes & Yes \\
State-level occupation FE & Yes & Yes & Yes & Yes & Yes \\
Constant & $3.632^{* * *}$ & $3.565^{* * *}$ & $3.478 * * *$ & $3.672 * * *$ & $3.386 * * *$ \\
& $(0.008)$ & $(0.030)$ & $(0.034)$ & $(0.032)$ & $(0.033)$ \\
\hline Observations & 22213 & 22213 & 22213 & 15433 & 6780 \\
$R^{2}$ & 0.044 & 0.085 & 0.192 & 0.183 & 0.331 \\
\hline
\end{tabular}

Notes: Standard errors are in parentheses. $* * *$ Significant at the $1 \%$ level; $* *$ significant at the $5 \%$ level; * significant at the $10 \%$ level. 
Table 5: Effects of the high school reform on the apprentice wages of high school graduates

\begin{tabular}{lccccc}
\hline In(apprentice wage HS degree) & Model 1 & Model 2 & Model 3 & $\begin{array}{c}\text { West } \\
\text { Germany }\end{array}$ & $\begin{array}{c}\text { East } \\
\text { Germany }\end{array}$ \\
\hline High school reform & $-0.009^{* *}$ & $-0.008^{*}$ & -0.002 & 0.002 & -0.017 \\
& $(0.004)$ & $(0.004)$ & $(0.005)$ & $(0.005)$ & $(0.014)$ \\
Year dummies & Yes & Yes & Yes & Yes & Yes \\
Occupational trends & No & Yes & Yes & Yes & Yes \\
State-level trends & No & No & Yes & Yes & Yes \\
State-level occupation FE & Yes & Yes & Yes & Yes & Yes \\
Constant & $2.895^{* * *}$ & $2.896^{* * *}$ & $2.907 * * *$ & $2.948^{* * *}$ & $2.724^{* * *}$ \\
& $(0.004)$ & $(0.005)$ & $(0.009)$ & $(0.009)$ & $(0.017)$ \\
\hline Observations & 6375 & 6375 & 6375 & 4660 & 1715 \\
$R^{2}$ & 0.489 & 0.509 & 0.535 & 0.491 & 0.617 \\
\hline
\end{tabular}

Notes: Standard errors are in parentheses. $* * *$ Significant at the $1 \%$ level; $* *$ significant at the $5 \%$ level; $*$ significant at the $10 \%$ level.

Table 6: Effects of the high school reform on the apprentice wages of lower secondary school graduates

\begin{tabular}{lccccc}
\hline $\begin{array}{l}\ln (\text { apprentice wage LS } \\
\text { degree) }\end{array}$ & Model 1 & Model 2 & Model 3 & $\begin{array}{c}\text { West } \\
\text { Germany }\end{array}$ & $\begin{array}{c}\text { East } \\
\text { Germany }\end{array}$ \\
\hline High school reform & $-0.013^{* * *}$ & $-0.013^{* * *}$ & -0.001 & -0.000 & -0.003 \\
& $(0.003)$ & $(0.003)$ & $(0.003)$ & $(0.003)$ & $(0.008)$ \\
Year dummies & Yes & Yes & Yes & Yes & Yes \\
Occupational trends & No & Yes & Yes & Yes & Yes \\
State-level trends & No & No & Yes & Yes & Yes \\
State-level occupation FE & Yes & Yes & Yes & Yes & Yes \\
Constant & $2.756^{* * *}$ & $2.751^{* * *}$ & $2.771^{* * *}$ & $2.834^{* * *}$ & $2.563^{* *}$ \\
& $(0.002)$ & $(0.004)$ & $(0.006)$ & $(0.006)$ & $(0.011)$ \\
\hline Observations & 10833 & 10833 & 10833 & 7594 & 3239 \\
$R^{2}$ & 0.602 & 0.632 & 0.654 & 0.629 & 0.702 \\
\hline
\end{tabular}

Notes: Standard errors are in parentheses. $* * *$ Significant at the $1 \%$ level; $* *$ significant at the $5 \%$ level; $*$ significant at the $10 \%$ level.

To allow for heterogeneity of the reform effects across occupations that differ in terms of the share of apprentices with a high school degree, we carried out some additional regressions. Interestingly, we find that the high school reform led to a homogenous increase in the number of apprenticeship contracts among individuals with a high school degree in West Germany, independent of the within-occupation share of apprentices with a high school degree (Table 
A3). In East Germany, however, the high school reform led to a disproportionately large increase in apprenticeship contracts in occupations where less than 50\% of apprentices hold a high school degree. ${ }^{14}$ However, we again find no statistically significant wage effects of the high school reform (Table A4).

\section{Elasticity of apprenticeship contracts and wages with respect to graduates}

In general, we expect markets to react to changes in supply. Indeed, our empirical results show that an increase in the number of high school graduates is positively associated with the number of new apprenticeship contracts. Table 7 shows that a $1 \%$ increase in the number of high school graduates is associated with an increase in the number of apprenticeship contracts of $0.15 \%$ in West Germany and $0.25 \%$ in East Germany. Our elasticity estimate is lower than that of Maier and Walden (2014), who report an elasticity of 0.60 based on a state-level analysis between 1983 and 2003. However, it is in line with the results of Baldi et al. (2014), who estimate an elasticity of 0.22 for the period 1999-2012.

Turning to apprentice wages, our results show no statistically significant relationship between the number of high school graduates and the wages of apprentices with a high school degree once we control for state-level trends (Model 3, Table 8). Although the point estimates are negative and statistically significant before including state-level trends (which may partly control for demographic changes as well), their economic significance is very low, as the coefficients indicate an elasticity of merely 0.05 (Models 1 and 2, Table 8). Including statelevel trends is important, however, because many collective bargaining agreements specify different wages across states. ${ }^{15}$

\footnotetext{
${ }^{14}$ Thus, sorting of high school graduates into training occupations differed between West and East Germany, which can also explain why we find negative wage effects when analyzing individual-level wage data in a pooled regression for East Germany (Table A2).

${ }^{15}$ We estimated the models reported in Table 7 and Table 8 also for apprentices with a lower secondary school degree. The results are similar, as we find a positive association between school graduates and the number of contracts, but no statistically significant association between school graduates and apprentice wages (see Tables A5 and A6).
} 
In the next subsection, we explicitly test whether the reform-induced increase in the supply of apprentices had a statistically significant effect on the number of apprenticeship contracts among and wages of apprentices with a high school degree.

Table 7: Elasticity of apprenticeship contracts with respect to high school graduates: Panel fixed-effects regression

\begin{tabular}{lcccc}
\hline $\begin{array}{l}\text { Dependent variable: } \\
\ln (\text { apprenticeship contracts HS degree) }\end{array}$ & Model 1 & Model 2 & $\begin{array}{c}\text { West } \\
\text { Germany }\end{array}$ & $\begin{array}{c}\text { East } \\
\text { Germany }\end{array}$ \\
\hline $\ln$ (graduates HS) & $0.335^{* * *}$ & $0.201 * * *$ & $0.152^{* * *}$ & $0.249 * * *$ \\
& $(0.014)$ & $(0.021)$ & $(0.025)$ & $(0.055)$ \\
Year dummies & Yes & Yes & Yes & Yes \\
Occupational trends & No & Yes & Yes & Yes \\
State-level trends & No & Yes & Yes & Yes \\
State and occupation FE & Yes & Yes & Yes & Yes \\
Constant & $-1.170 * * *$ & -1.002 & $0.464 * *$ & -0.512 \\
& $(0.133)$ & $(0.199)$ & $(0.236)$ & $(0.521)$ \\
\hline Observations & 23470 & 23470 & 16237 & 7233 \\
$R^{2}$ & 0.051 & 0.211 & 0.252 & 0.204 \\
\hline
\end{tabular}

Notes: Standard errors are in parentheses. $* * *$ Significant at the $1 \%$ level; $* *$ significant at the $5 \%$ level; * significant at the $10 \%$ level.

Table 8: Elasticity of apprentice wages with respect to high school graduates: Panel fixedeffects regression

\begin{tabular}{lccccc}
\hline $\begin{array}{l}\text { Dependent variable: } \\
\text { ln(apprentice wage HS } \\
\text { degree) }\end{array}$ & Model 1 & Model 2 & Model 3 & $\begin{array}{c}\text { West } \\
\text { Germany }\end{array}$ & $\begin{array}{c}\text { East } \\
\text { Germany }\end{array}$ \\
\hline $\ln$ (graduates HS) & $-0.052^{* * *}$ & $-0.049 * * *$ & -0.002 & 0.006 & -0.036 \\
& $(0.006)$ & $(0.006)$ & $(0.008)$ & $(0.009)$ & $(0.027)$ \\
Year dummies & Yes & Yes & Yes & Yes & Yes \\
Occupational trends & No & Yes & Yes & Yes & Yes \\
State-level trends & No & No & Yes & Yes & Yes \\
State-level occupation FE & Yes & Yes & Yes & Yes & Yes \\
Constant & $3.388^{* * *}$ & $3.365^{* * *}$ & $2.817 * * *$ & $2.846 * * *$ & $3.055^{* * *}$ \\
& $(0.054)$ & $(0.054)$ & $(0.079)$ & $(0.091)$ & $(0.261)$ \\
\hline Observations & 6375 & 6375 & 6375 & 4660 & 1715 \\
$R^{2}$ & 0.497 & 0.516 & 0.535 & 0.491 & 0.617 \\
\hline
\end{tabular}

Notes: Standard errors are in parentheses. $* * *$ Significant at the $1 \%$ level; $* *$ significant at the $5 \%$ level; $*$ significant at the $10 \%$ level. 


\section{Instrumental variable estimation}

Our first-stage estimates in Table 9 clearly show the strength of the effect of the high school reform on the number of high school graduates. On average, the high school reform increased the number of apprenticeship contracts among individuals with a high school degree by $\exp (0.5)$, or approximately $65 \%$. The second-stage results are similar to those reported in Table 7. In West Germany, a 1\% increase in the supply of high school graduates is associated with a $0.14 \%$ increase in the number of apprenticeship contracts among individuals with a high school degree (Table 9). These results suggest that firms absorbed the increase in the supply of apprentices with a high school degree in a way similar to that of other years, despite the marked reform-induced increase in graduation rates. ${ }^{16}$

Table 9: Elasticity of apprenticeship contracts with respect to high school graduates: Instrumental variable panel fixed-effects regression First stage: $\ln$ (graduates $H S) \quad$ Second stage: $\ln$ (apprenticeship contracts)

\begin{tabular}{lccccccc} 
& $\begin{array}{c}\text { Full } \\
\text { sample }\end{array}$ & $\begin{array}{c}\text { West } \\
\text { Germany }\end{array}$ & $\begin{array}{c}\text { East } \\
\text { Germany }\end{array}$ & Model 1 & Model 2 & $\begin{array}{c}\text { West } \\
\text { Germany }\end{array}$ & $\begin{array}{c}\text { East } \\
\text { Germany }\end{array}$ \\
\hline High school reform & $0.500^{* * *}$ & $0.504 * * *$ & $0.458^{* * *}$ & & & & \\
& $(0.002)$ & $(0.001)$ & $(0.004)$ & & & & \\
$\ln$ (graduates HS) & & & & $0.181^{* * *}$ & $0.155^{* * *}$ & $0.139 * * *$ & $0.269 * * *$ \\
& & & & $(0.019)$ & $(0.024)$ & $(0.025)$ & $(0.065)$ \\
Year dummies & Yes & Yes & Yes & Yes & Yes & Yes & Yes \\
Occupational trends & Yes & Yes & Yes & No & Yes & Yes & Yes \\
State-level trends & Yes & Yes & Yes & No & Yes & Yes & Yes \\
State and occupation & & & & & & & \\
FE & Yes & Yes & Yes & Yes & Yes & Yes & Yes \\
Constant & $9.479 * * *$ & $9.504 * * *$ & $9.208 * * *$ & 0.254 & $0.424 *$ & $0.595 * *$ & -0.696 \\
& $(0.007)$ & $(0.003)$ & $(0.008)$ & $(0.184)$ & $(0.221)$ & $(0.243)$ & $(0.607)$ \\
\hline Observations & 23470 & 16237 & 7233 & 23470 & 23470 & 16237 & 7233 \\
\hline
\end{tabular}

Notes: Standard errors are in parentheses. $* * *$ Significant at the $1 \%$ level; $* *$ significant at the $5 \%$ level; * significant at the $10 \%$ level.

\footnotetext{
${ }^{16}$ The results remain qualitatively similar when restricting the analysis to occupations with a share of high school graduates between 0.25 and 0.75 (i.e., to occupations with an intermediate share of apprentices with a high school degree).
} 
Moreover, Table 10 also confirms the results of our panel fixed effects estimates in Table 6, as we find no empirical evidence that the high school reform-induced increase in the supply of high school graduates affected apprentice wages. While the results are not statistically significant, the point estimate for East Germany is negative (but still small in terms of its economic significance). Thus, as in regular years, our results suggest that the growth in apprentice wages for individuals with a high school degree is driven by factors other than the supply of high school graduates in a state. In summary, our empirical evidence suggests that $x_{N A}^{1}=x_{N A}^{0}$ and $x_{A}^{1}>x_{A}^{0}$, while $w_{N A}^{1}=w_{N A}^{0}$ and $w_{A}^{1}=w_{A}^{0}$, which supports the notion that the market can be characterized by excess demand for apprentices with a high school degree.

Table 10: Elasticity of apprentice wages with respect to high school graduates: Instrumental variable panel fixed-effects regression

\begin{tabular}{|c|c|c|c|c|c|c|c|}
\hline & \multicolumn{3}{|c|}{ First stage: $\ln ($ graduates $H S)$} & \multicolumn{4}{|c|}{ Second stage: $\ln ($ apprentice wage) } \\
\hline & $\begin{array}{c}\text { Full } \\
\text { sample }\end{array}$ & $\begin{array}{c}\text { West } \\
\text { Germany }\end{array}$ & $\begin{array}{c}\text { East } \\
\text { Germany }\end{array}$ & Model 1 & Model 2 & $\begin{array}{c}\text { West } \\
\text { Germany }\end{array}$ & $\begin{array}{c}\text { East } \\
\text { Germany }\end{array}$ \\
\hline High school reform & $\begin{array}{c}0.493 * * * \\
(0.003)\end{array}$ & $\begin{array}{c}0.496 * * * \\
(0.002)\end{array}$ & $\begin{array}{r}0.437 * * * \\
(0.0073)\end{array}$ & & & & \\
\hline $\ln$ (graduates HS) & & & & $\begin{array}{c}-0.016^{* *} \\
(0.008)\end{array}$ & $\begin{array}{l}-0.003 \\
(0.009)\end{array}$ & $\begin{array}{c}0.004 \\
(0.009)\end{array}$ & $\begin{array}{l}-0.039 \\
(0.033)\end{array}$ \\
\hline Year dummies & Yes & Yes & Yes & Yes & Yes & Yes & Yes \\
\hline Occupational trends & Yes & Yes & Yes & No & Yes & Yes & Yes \\
\hline State-level trends & Yes & Yes & Yes & No & Yes & Yes & Yes \\
\hline State and occupation FE & Yes & Yes & Yes & Yes & Yes & Yes & Yes \\
\hline Constant & $\begin{array}{c}9.306^{* * * *} \\
(0.006)\end{array}$ & $\begin{array}{c}9.566^{* * * *} \\
(0.004)\end{array}$ & $\begin{array}{c}9.237 * * * \\
(0.007)\end{array}$ & $\begin{array}{c}3.051 * * * \\
(0.073)\end{array}$ & $\begin{array}{c}2.939 * * * \\
(0.088)\end{array}$ & $\begin{array}{c}2.913 * * * \\
(0.091)\end{array}$ & $\begin{array}{c}3.084 * * * \\
(0.304)\end{array}$ \\
\hline Observations & 6375 & 4660 & 1715 & 6375 & 6375 & 4660 & 1715 \\
\hline
\end{tabular}

Notes: Standard errors are in parentheses. $* * *$ Significant at the $1 \%$ level; $* *$ significant at the $5 \%$ level; * significant at the $10 \%$ level.

\section{Robustness checks}

We further analyze subsamples and consider different pairs of German states affected by the high school reform in different years to check whether our results are robust to a comparison of neighboring states that share a similar economic structure (e.g., Bavaria and Baden- 
Wuerttemberg) or non-bordering states in which few apprentices are expected to move across state borders in the control state, as the distance is too far (e.g., Bavaria and North RhineWestphalia). Table 11 shows that the results based on these subsamples broadly confirm the previous results based on the full sample, where we found an average reform-induced increase of $7 \%$ in West Germany, although some of the point estimates (e.g., for BW \& NW and BW\& SL) tend to be somewhat higher. We also conduct a subsample analysis by occupational group (at the one-digit level) to test whether demographic fluctuations in the number of high school graduates may affect apprentice wages differently in homogeneous occupational groups. However, as shown in Table 12, none of the coefficients are statistically significant, although seven of the nine point estimates are negative (but small in absolute value).

Table 11: Elasticity of apprenticeship contracts with respect to high school graduates: Subsamples and panel fixed-effects regression

\begin{tabular}{lcccccc}
\hline $\begin{array}{l}\text { Dependent variable: } \\
\text { ln(contracts HS degree) }\end{array}$ & BY \& BW & BY \& NW & BY \& NI & BW \& NW & BW \& RP & BW \& SL \\
\hline High school reform & $0.080^{* * *}$ & 0.040 & $0.085^{* *}$ & $0.114^{* *}$ & $0.090^{*}$ & $0.157 * * *$ \\
& $(0.029)$ & $(0.026)$ & $(0.027)$ & $(0.028)$ & $(0.052)$ & $(0.037)$ \\
Year dummies & Yes & Yes & Yes & Yes & Yes & Yes \\
Occupational trends & Yes & Yes & Yes & Yes & Yes & Yes \\
State-level trends & Yes & Yes & Yes & Yes & Yes & Yes \\
State-level occupation FE & Yes & Yes & Yes & Yes & Yes & Yes \\
Constant & $2.115 * * *$ & $2.456 * * *$ & $2.064 * *$ & $2.459 * *$ & $1.919 * *$ & $1.875^{* * *}$ \\
& $(0.058)$ & $(0.055)$ & $(0.066)$ & $(0.057)$ & $(0.060)$ & $(0.063)$ \\
\hline Observations & 3893 & 4268 & 3809 & 4247 & 3478 & 3089 \\
R-squared & 0.370 & 0.384 & 0.392 & 0.346 & 0.368 & 0.306 \\
\hline
\end{tabular}

Notes: Standard errors are in parentheses. BW=Baden-Württemberg, BY=Bavaria, NI=Lower Saxony, $\mathrm{HB}=$ Bremen, $\mathrm{NW}=$ North Rhine-Westphalia, $\mathrm{RP}=$ Rhineland-Palatinate, $\mathrm{SL}=$ Saarland. $* * *$ Significant at the $1 \%$ level; ** significant at the $5 \%$ level; * significant at the $10 \%$ level.

We further check whether there were any anticipation effects of reform-induced increases in graduation rates. Clearly, firms were aware that graduation rates would increase in a particular year, and thus, they could have altered their training behavior in the year before the supply shock. 
The results in Table 13 show no statistically significant anticipation effects in West Germany, although we find a marginally significant and negative effect for East Germany. An explanation for this effect can be found in Figure 3 and Table 1, where both the number of high school graduates and (consequently) the share of apprentices with a high school degree decreased sharply in East German states between 2008 and 2011, likely because of demographic changes as well as the financial crisis and the associated migration of workers to other states. That period coincides with the build-up to the year in which the double cohort of high school students graduated in the state of Brandenburg.

Table 12: Elasticity of apprentice wages with respect to high school graduates: Three-digit occupational fields, panel fixed-effects regression

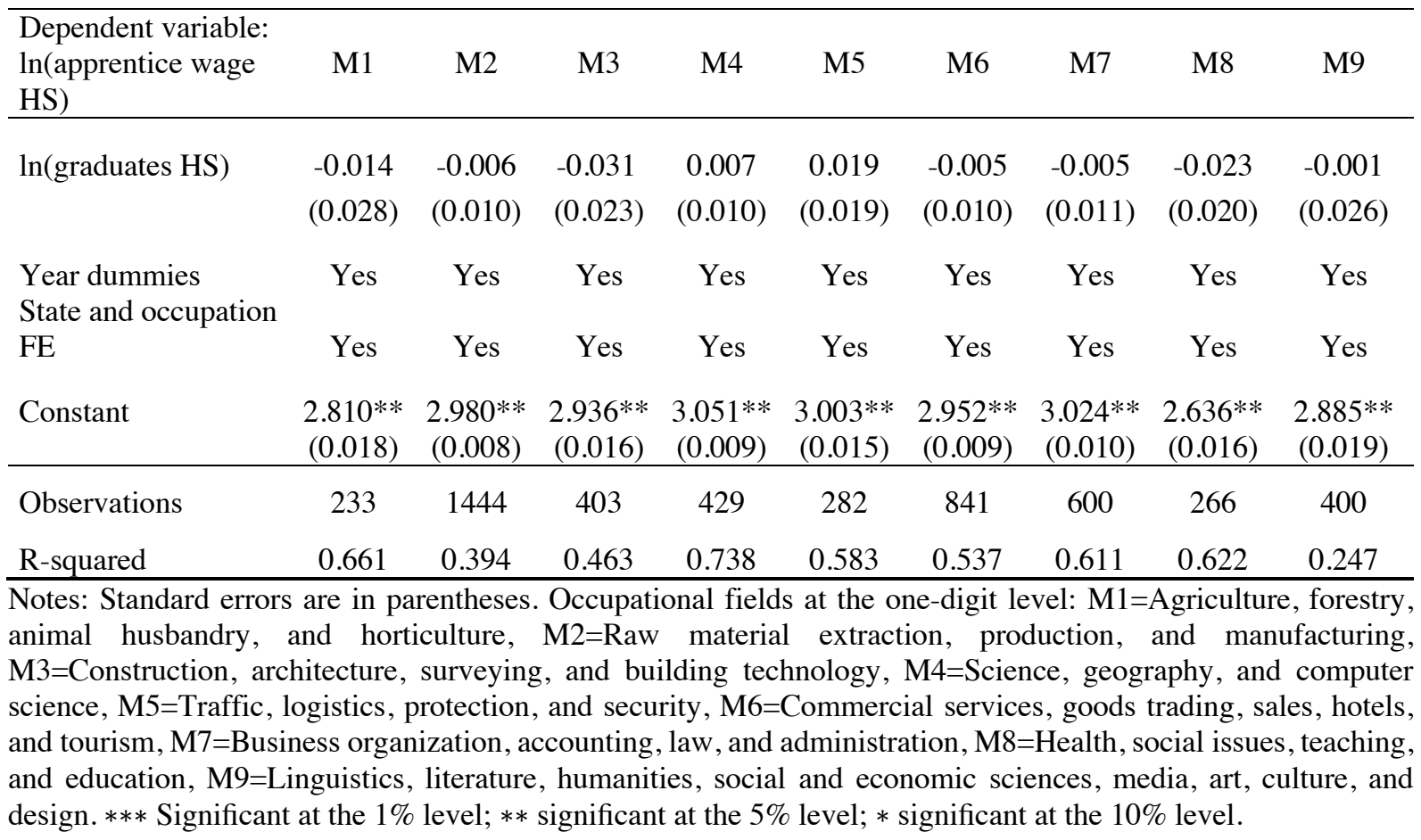


Table 13: Placebo test: Anticipation effects of the high school reform on the number of contracts

\begin{tabular}{lccccc}
\hline $\begin{array}{l}\text { Dependent variable: } \\
\ln \text { (contracts HS degree) }\end{array}$ & Model 1 & Model 2 & Model 3 & $\begin{array}{c}\text { West } \\
\text { Germany }\end{array}$ & $\begin{array}{c}\text { East } \\
\text { Germany }\end{array}$ \\
\hline$G 8_{t+1}$ & $-0.022^{* *}$ & $-0.025^{* *}$ & $-0.033^{* * *}$ & -0.016 & $-0.075^{*}$ \\
& $(0.013)$ & $(0.012)$ & $(0.016)$ & $(0.013)$ & $(0.039)$ \\
Year dummies & Yes & Yes & Yes & Yes & Yes \\
Occupational-level trends & No & Yes & Yes & Yes & Yes \\
State-level trends & No & No & Yes & Yes & Yes \\
State-level occupation FE & Yes & Yes & Yes & Yes & Yes \\
Constant & $2.024 * * *$ & $1.908^{* * *}$ & $1.849 * * *$ & $1.918 * * *$ & $1.825 * * *$ \\
& $(0.010)$ & $(0.027)$ & $(0.031)$ & $(0.036)$ & $(0.065)$ \\
\hline Observations & 23470 & 23470 & 23470 & 16237 & 7233 \\
R-squared & 0.023 & 0.014 & 0.207 & 0.250 & 0.202 \\
\hline
\end{tabular}

Notes: Standard errors are in parentheses. *** Significant at the $1 \%$ level; ** significant at the $5 \%$ level; * significant at the $10 \%$ level.

\section{Discussion}

When a positive supply shock occurs in a competitive market, the equilibrium wage falls, and the number of contracts increases. In Germany, such an adjustment could not be observed in response to a strong one-time supply shock that was the result of a school reform. While we identified an increase in the number of apprenticeship contracts with individuals holding a high school degree, we found no empirical evidence for substitution effects (i.e., a reduction in the number of apprentices with a lower school degree). Figure A2 illustrates the situation for apprenticeships and their institutionally restricted wage setting rules in Germany. Adjustment to the equilibrium level $w_{A}^{*}$ does not occur since demand for highly educated apprentices is too high and the collectively set wage level $w_{A}^{*}$ is too low to clear the market. These results support the notion that the market for apprentices with a high education level is characterized by excess demand, which can occur due to sticky wages. In Germany, collectively bargained wages do not formally differ by the educational qualifications of apprentices. Thus, to improve the efficiency of the market for apprentices with a high school degree, a cost-effective measure 
would be to allow wages to differ by the education level of an apprentice in collective agreements.

Although wages are sticky in the short run, firms may in turn find other ways to increase the attractiveness of apprenticeships for high school graduates (Göggel and Zwick, 2012). For example, more firms are starting to offer a combination of apprenticeships and university studies at the bachelor level. This "dual study" contract, demanding as it may be for high school apprentices, implies that apprentices spend less time in the firm and can allocate more time to their studies. Such a setting implicitly increases the hourly wage. Furthermore, regulations provide the option for high school graduates to shorten their training period by up to one year before signing the training contract. Apprentices then enter the second year of training straight away, receive a potentially higher starting wage and thus increase their individual rate of return to education.

Our results also have implications for future supply shocks in the apprenticeship market. As firms seem to be unable to adjust wages downwards in the short run, supply shocks such as the recent wave of migrants in 2015 may lead to the transitional unemployment of applicants for apprenticeships or a strong increase in individuals in the transitory system. Such a scenario is particularly relevant for migrants with lower secondary schooling degrees who often have below-average cognitive skills (particularly a lack of language skills). Thus, in contrast to highly educated apprentices, firms are unlikely to have excess demand for this group of apprenticeship applicants. As a result, corresponding supply shocks would not be absorbed by the apprenticeship market, which is in line with the observation that in each year of our observation period, between 200,000 and 300,000 individuals (a large majority of them with a low schooling degree) were not successful in securing an apprenticeship contract and instead ended up in transitory vocational programs (BIBB 2017a). 


\section{Conclusion}

Recent trends towards academization are visible in many countries, with an increasing share of individuals enrolling in colleges and universities. However, we find that in recent years, apprenticeships have increased in popularity among German school graduates, even though such students could directly access a university education through their degree. This study analyzed the working of the market for highly educated apprentices. Specifically, it studied the effects of a recent school reform in Germany that led to a positive one-time supply shock of highly educated school graduates in the apprenticeship training market. Our results show that firms contracted with more apprentices with a high school degree without reducing demand for lower school graduates. Contrary to the prediction of theory under the assumptions of competitive markets, however, the increased supply of highly educated apprentices was absorbed by training firms without a reduction in apprentice wages. These findings support the notion that the market for high school apprentices is characterized by excess demand as a result of sticky wages in the German apprenticeship market. While wage stickiness may be associated with institutional factors such as collective bargaining agreements or works councils, empirically identifying the causes of sticky wages is beyond the scope of this paper and is therefore left for future research. However, from a policy perspective, increasing the flexibility of wage arrangements, especially for highly educated individuals, might help to improve the efficiency of the German apprenticeship market. 


\section{References}

Acemoglu, D. and Pischke, J.-S. (1999). Beyond Becker: Training in imperfect labour markets. Economic Journal 109, pp. 112-142.

Antoni, M., Schmucker, A., Seth, S. and vom Berge, P. (2019): Sample of integrated labour market biographies (SIAB) 1975-2017. FDZ-Datenreport, 02/2019 (en). Nuremberg: Institute for Employment Research.

Baldi, G., Brüggemann-Borck, I., and Schlaak, T. (2014). The effect of the business cycle on apprenticeship training: Evidence from Germany. Journal of Labor Research 35(4), pp. 412422.

Borjas, G. J. (2003). The labor demand curve $\underline{I S}$ downward sloping. Quarterly Journal of Economics 118(4), pp. 1335-1374.

Borjas, G. J. (2015). Labor Economics. McGraw-Hill, 7th edition.

BIBB (2017a). VET Data Report Germany [BIBB Datenreport zum Berufsbildungsbericht] 2017. Bonn: Bundesinstitut für Berufsbildung.

https://www.bibb.de/dokumente/pdf/bibb_datenreport_2017.pdf

BIBB (2017b). Verzeichnis der anerkannten Ausbildungsberufe. Bonn.

Blatter, M., Muehlemann, S., Schenker, S. and Wolter, S.C. (2016),"Hiring costs of skilled workers and the supply of firm-provided training", Oxford Economic Papers 68 (1), pp. 238257

Büttner, B. and Thomsen, S.L. (2015). Are we spending too many years in school? Causal evidence of the impact of shortening secondary school duration. German Economic Review 16 (1), pp. 65-86.

Cavaglia, C., McNally, S. and Ventura, G. (2020). Do Apprenticeships Pay? Evidence for England. Oxford Bulletin of Economics and Statistics (forthcoming).

Dahmann, S.C. (2017). How does education improve cognitive skills? Instructional time versus timing of instruction. Labour Economics 47, pp. 35-47.

Dahmann, S.C. and Anger, S. (2014). The impact of education on personality: Evidence from a German high school reform. IZA Discussion Papers 8139.

Destatis (2016). Fachserie 11 - Bildung und Kultur, Reihe 1. Federal Statistical Office Wiesbaden.

Destatis (2019). Fachserie 11 - Bildung und Kultur, Reihe 1. Federal Statistical Office Wiesbaden.

Dustmann, C., and Schoenberg, U. (2009). Training and union wages. The Review of Economics and Statistics, 91(2), 363-376. 
Dustmann, C., Schönberg, U., and Stuhler, J. (2017). Labor supply shocks, native wages, and the adjustment of local employment. Quarterly Journal of Economics 132, pp. 435-483.

Göggel, K., and Zwick, T. (2012). Heterogeneous wage effects of apprenticeship training. The Scandinavian Journal of Economics, 114(3), 756-779.

Jansen, A., de Grip, A., and Kriechel, B. (2017). The effect of choice options in training curricula on the demand for and supply of apprentices. Economics of Education Review 57, 5265 .

Maier, T., and Walden, G. (2014). The influence of demographic factors on the supply of company training places in Germany. Empirical Research in Vocational Education and Training 6(4), pp. 1-14.

Meyer, T. and Thomsen, S.C. (2017). The role of high-school duration for university students' motivation, abilities and achievements. Education Economics 26(1), pp. 24-45.

Pischke, J.-S. and Velling, J. (1997). Employment effects of immigration to Germany: An analysis based on local labor markets. Review of Economics and Statistics 79(4), pp. 594-604.

Ryan, P. (2001). The school-to-work transition: a cross-national perspective. Journal of Economic Literature, 39(1), 34-92.

Schnabel, C. (2016). United, Yet Apart? A Note on Persistent Labour Market Differences between Western and Eastern Germany. Jahrbücher für Nationalökonomie und Statistik 236(2), pp. 157-179.

Stevens, M. (1999). Human capital theory and UK vocational training policy. Oxford Review of Economic Policy, Spring, 15(1), 16-32.

Wolter, S.C. and Ryan, P. (2011). Apprenticeship. Handbook of Economics of Education, Vol. 3, ed. by R. Hanushek, S. Machin, L. Woessmann, Amsterdam: Elsevier North-Holland, pp. 521-576.

Woessmann, L. (2016). The importance of school systems: Evidence from international differences in student achievement. Journal of Economic Perspectives, 30(3), 3-32. 


\section{Appendix A}

Apprenticeship output $y$ is produced according to a CES technology $y=\left(\alpha x_{A}^{\rho}+(1-\alpha) x_{N A}^{\rho}\right)^{\frac{1}{\rho}}$, where $0<\alpha<1$ is the constant share parameter and $-\infty<\rho \leq$ 1 determines the degree of substitutability between $x_{A}$ and $x_{N A}$. The marginal costs of apprentices are fixed and differ between the two types of apprenticeships, with $w_{A} \geq w_{N A}>0$. In the short run, output $\bar{y}$ is constant. Firms minimize their expected training costs $w_{A} x_{A}+$ $w_{N A} x_{N A}$ subject to $\bar{y}$.

The Lagrangian function for this problem is

A1. $\quad \mathcal{L}\left(x_{A}, x_{N A}, \lambda \mid w_{A}, w_{N A}, \bar{y}\right)=w_{A} x_{A}+w_{N A} x_{N A}+\lambda\left(\bar{y}-\left(\alpha x_{A}^{\rho}+(1-\alpha) x_{N A}^{\rho}\right)^{\frac{1}{\rho}}\right)$.

The first-order conditions are $\mathcal{L}_{A}=\frac{\partial \mathcal{L}}{\partial x_{A}}=0, \mathcal{L}_{N A}=\frac{\partial \mathcal{L}}{\partial x_{N A}}=0$, and $\mathcal{L}_{\lambda}=\frac{\partial \mathcal{L}}{\partial \lambda}=0$. The first two conditions show that at the point of equilibrium, the isoquant curve is tangent to the isocost line A2. $\quad \frac{w_{A}}{w_{N A}}=\frac{\alpha}{1-\alpha}\left(\frac{x_{A}}{x_{N A}}\right)^{\rho-1}$.

The point of tangency determines the equilibrium inputs $x_{A}^{*}$ and $x_{N A}^{*}$ at output level $\bar{y}$. Rewrite A2 in terms of $x_{A}$ and $x_{N A}$. Substituting into $\mathcal{L}_{\lambda}$ obtains the short-run demand functions for the two types of apprenticeships:

A3i.

$$
x_{A}^{*}\left(w_{A}, w_{N A}, \bar{y}\right)=\frac{\bar{y}\left(\frac{w_{A}}{\alpha}\right)^{\frac{1}{\rho-1}}}{\left(\alpha\left(\frac{w_{A}}{\alpha}\right)^{\frac{\rho}{\rho-1}}+(1-\alpha)\left(\frac{w_{N A}}{1-\alpha}\right)^{\frac{\rho}{\rho-1}}\right)^{\frac{1}{\rho}}} \text { and }
$$

A3ii.

$$
x_{N A}^{*}\left(w_{A}, w_{N A}, \bar{y}\right)=\frac{\bar{y}\left(\frac{w_{N A}}{1-\alpha}\right)^{\frac{1}{\rho-1}}}{\left(\alpha\left(\frac{w_{A}}{\alpha}\right)^{\frac{\rho}{\rho-1}}+(1-\alpha)\left(\frac{w_{N A}}{1-\alpha}\right)^{\frac{\rho}{\rho-1}}\right)^{\frac{1}{\rho}}} .
$$

The cost function is $c\left(w_{A}, w_{N A}, y\right)=w_{A} x_{A}^{*}\left(w_{A}, w_{N A}, y\right)+w_{N A} x_{N A}^{*}\left(w_{A}, w_{N A}, y\right)$.

Define $\gamma \equiv\left(\alpha\left(\frac{w_{A}}{\alpha}\right)^{\frac{\rho}{\rho-1}}+(1-\alpha)\left(\frac{w_{N A}}{1-\alpha}\right)^{\frac{\rho}{\rho-1}}\right)^{-\frac{1}{\rho}}$. Now, it is straightforward to show that the marginal and average costs are the same and do not depend on the level of output:

$$
\frac{c\left(w_{A}, w_{N A}, y\right)}{y}=\frac{\partial c\left(w_{A}, w_{N A}, y\right)}{\partial y}=\gamma\left(w_{A}\left(\frac{w_{A}}{\alpha}\right)^{\frac{1}{\rho-1}}+w_{N A}\left(\frac{w_{N A}}{1-\alpha}\right)^{\frac{1}{\rho-1}}\right) \text {. }
$$


Figure A1: Map of the implementation of the high school reform

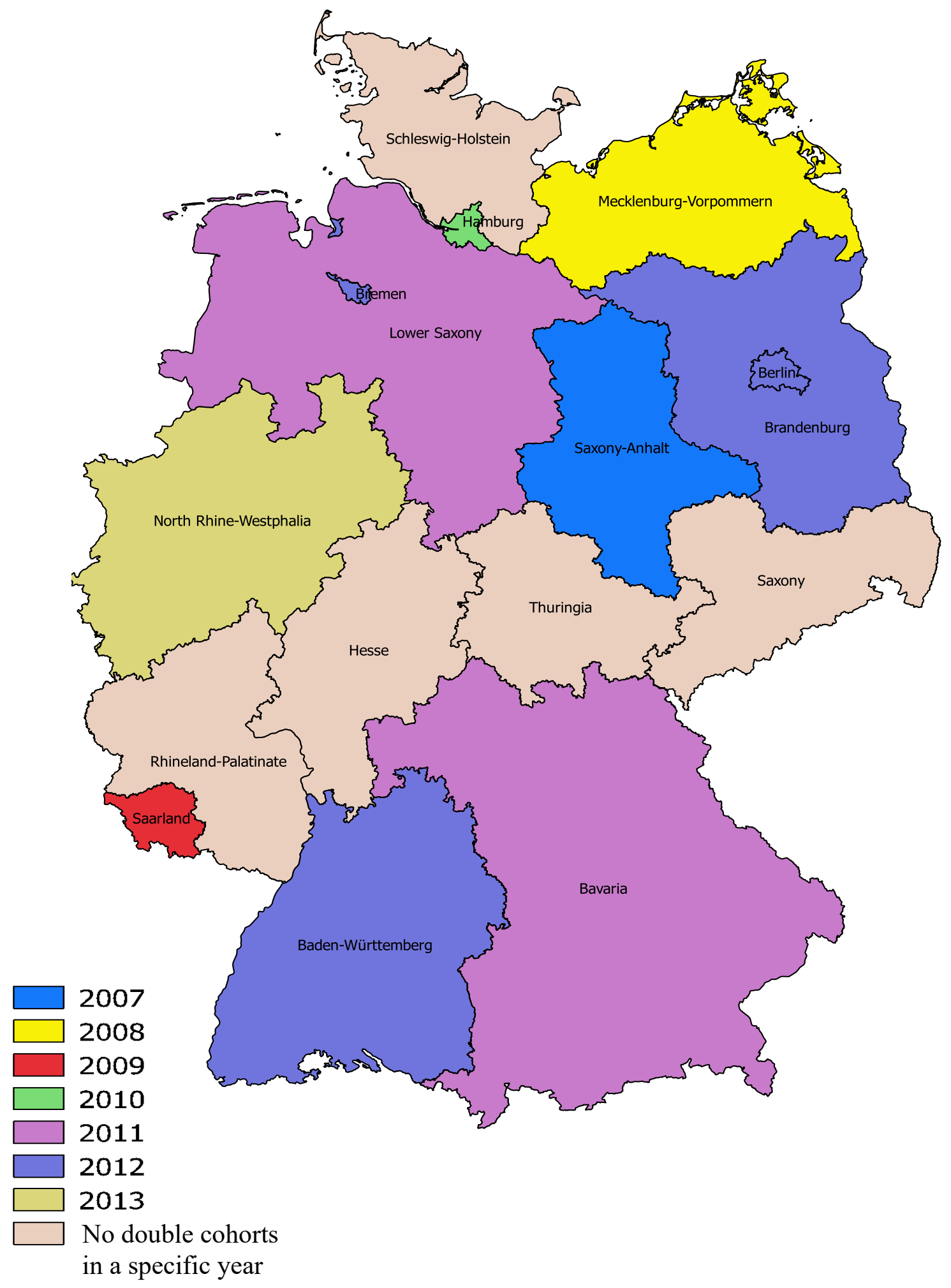


Figure A2: Highly inelastic or complementary demand for highly educated apprentices

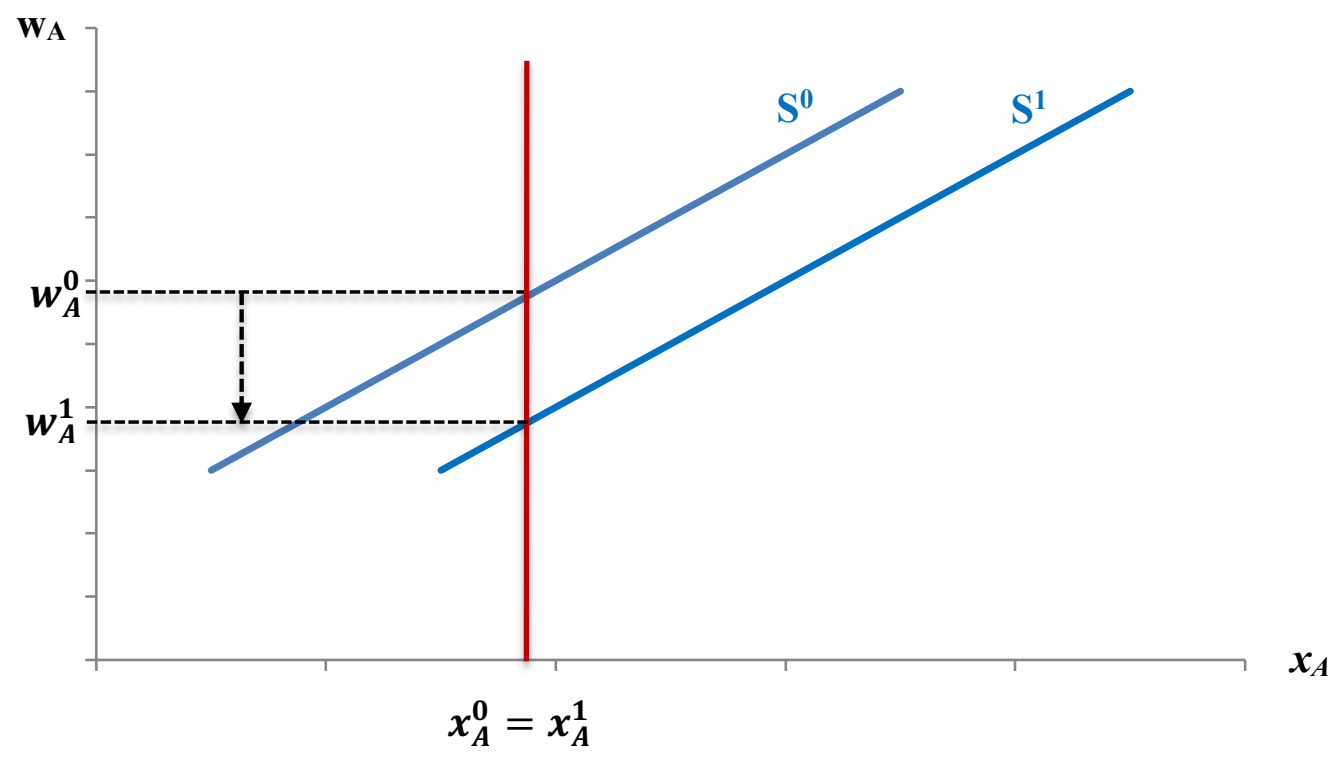

Figure A3: Highly elastic or excess demand for highly educated apprentices

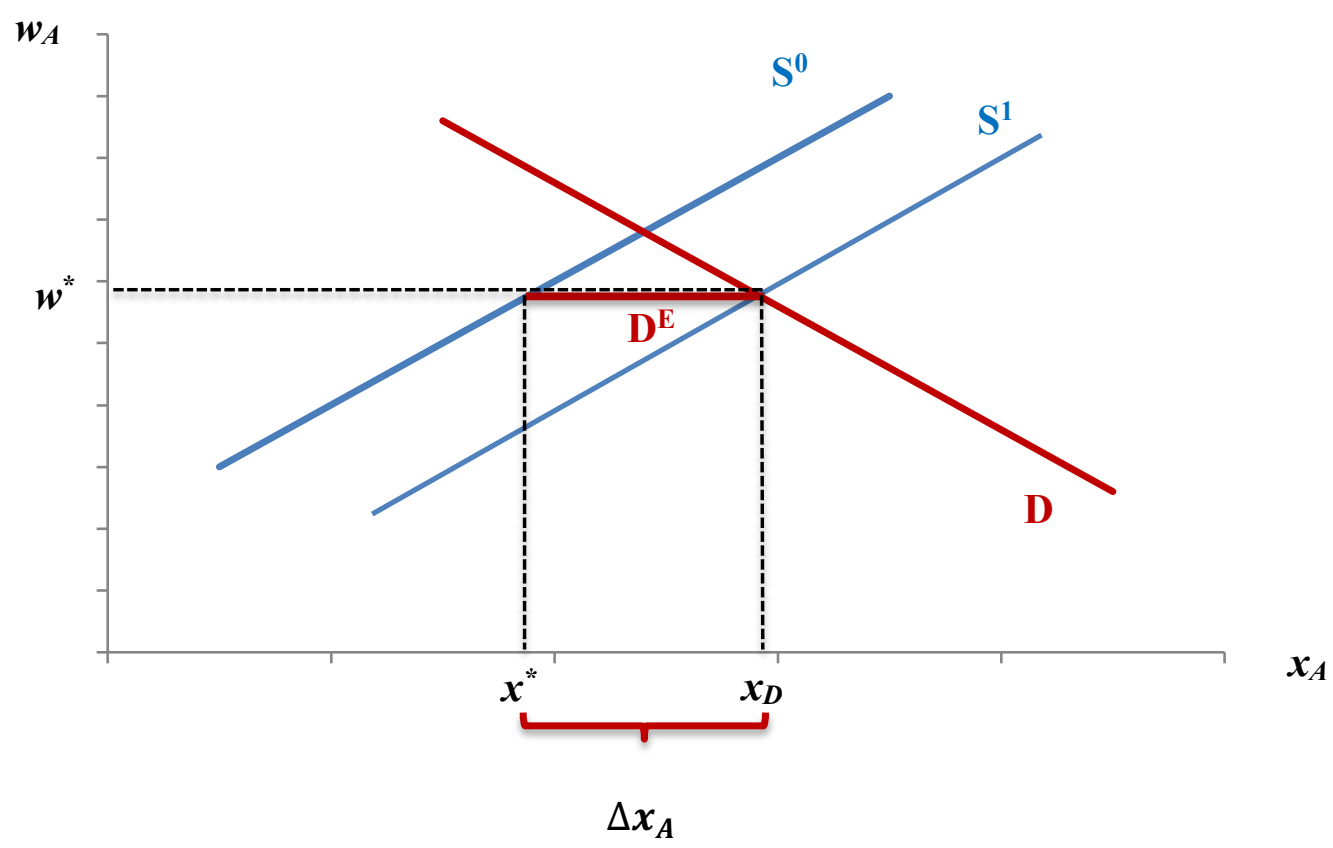


Figure A4: Distribution of the share of high school apprentices across occupations

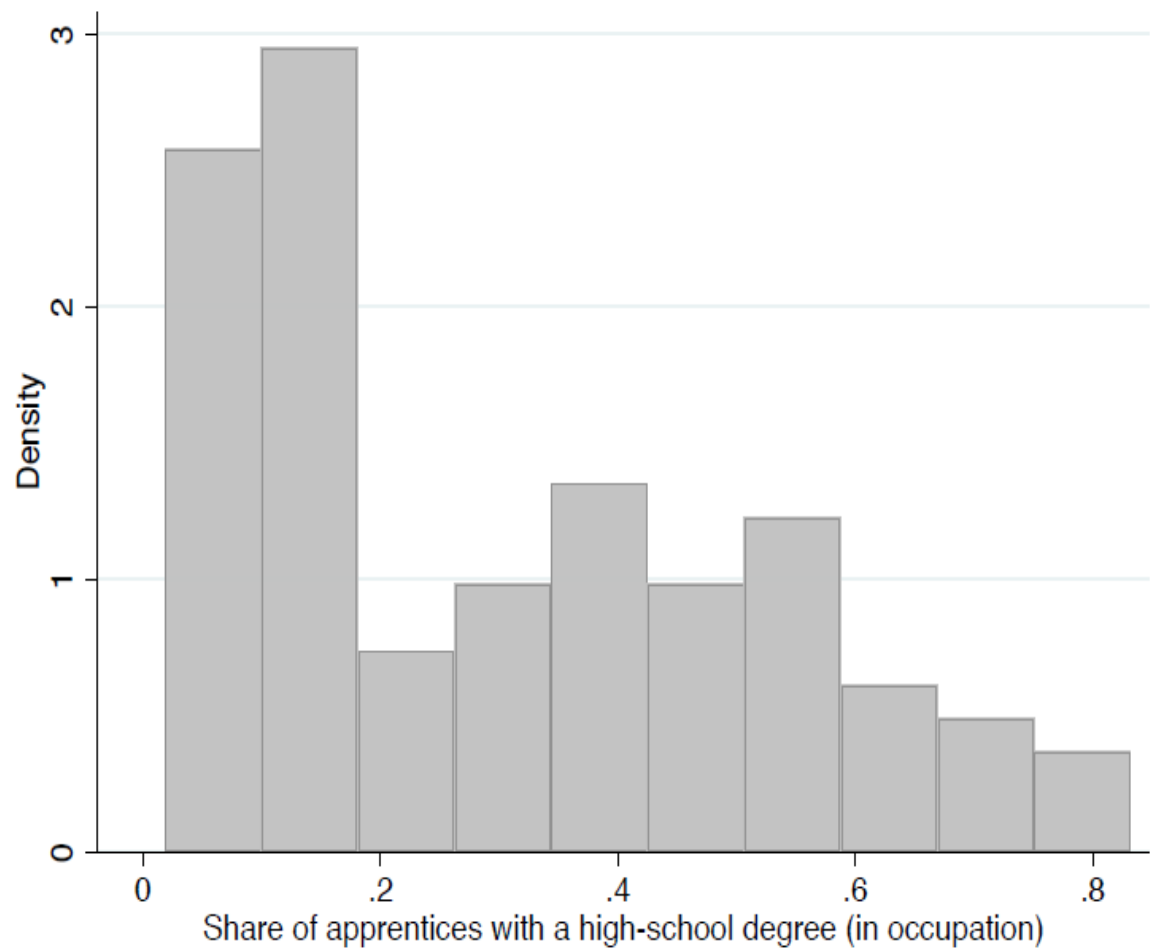

Source: Federal Statistical Office contract data. 
Table A1: Share of apprentices with residence in the same state as their workplace

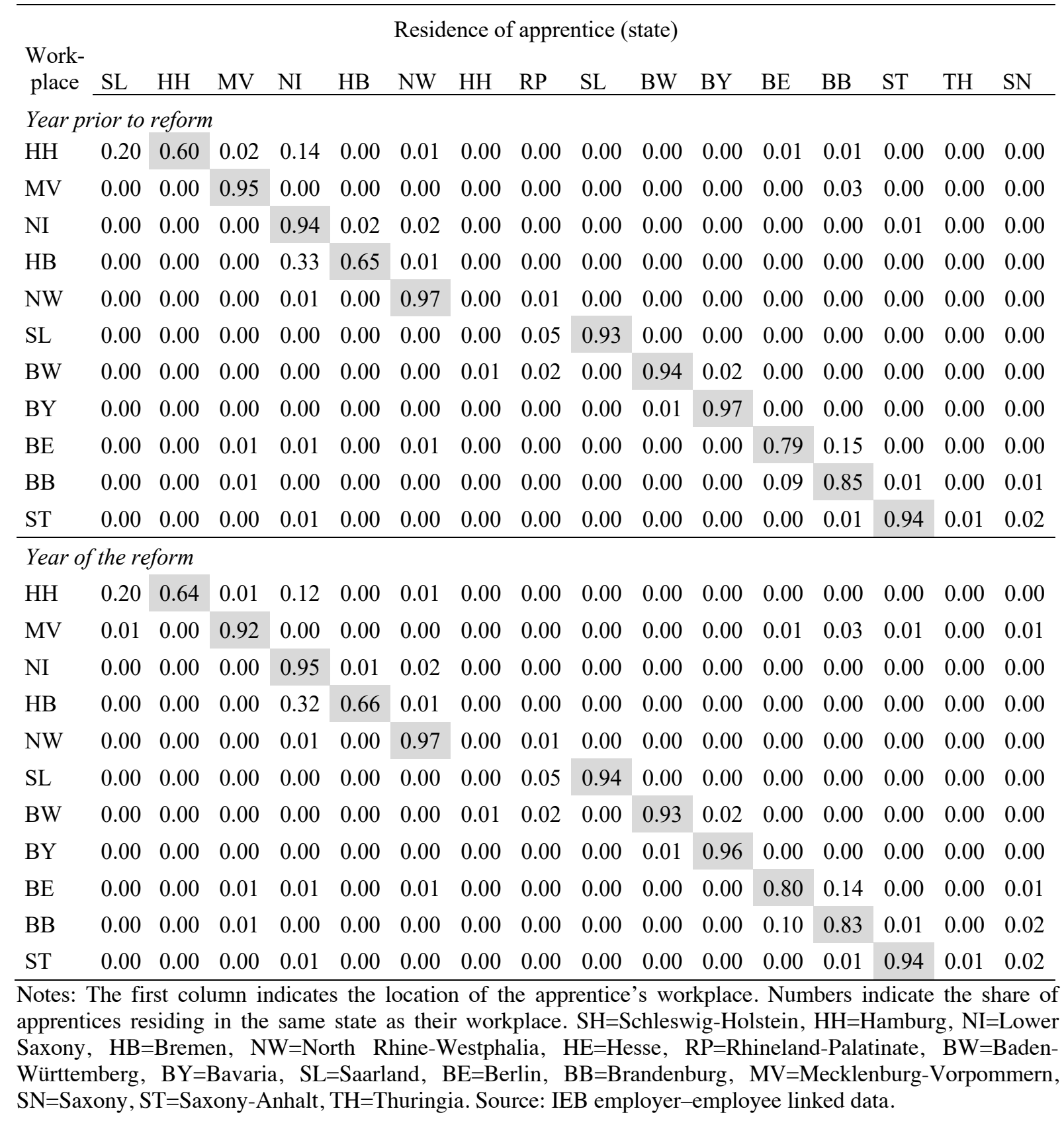


Table A2: Effects of the high school reform on apprentice wages using individual wage data

\begin{tabular}{lcccccc}
\hline $\ln ($ apprentice wage) & $w_{a}^{H S}$ & $w_{a, W E S T}^{H S}$ & $w_{a, E A S T}^{H S}$ & $w_{a}^{\text {nonHS }}$ & $w_{a, W E S T}^{\text {nonHS }}$ & $w_{a, E A S T}^{\text {nonHS }}$ \\
& $(1)$ & $(2)$ & $(3)$ & $(4)$ & $(5)$ & $(6)$ \\
\hline High school reform & $0.002^{*}$ & $0.007^{* * *}$ & 0.006 & $-0.014^{* * *}$ & $-0.007 * * *$ & $-0.020^{* * * *}$ \\
& $(0.001)$ & $(0.001)$ & $(0.005)$ & $(0.001)$ & $(0.001)$ & $(0.002)$ \\
Year dummies & Yes & Yes & Yes & Yes & Yes & Yes \\
Occupation dummies & Yes & Yes & Yes & Yes & Yes & Yes \\
State dummies & Yes & Yes & Yes & Yes & Yes & Yes \\
Constant & $2.812^{* * *}$ & $2.825^{* * *}$ & $2.767 * * *$ & $2.647^{* * *}$ & $2.655^{* * *}$ & $2.574^{* * *}$ \\
& $(0.006)$ & $(0.00526)$ & $(0.0174)$ & $(0.002)$ & $(0.002)$ & $(0.005)$ \\
\hline Observations & 653,542 & 565,237 & 88,305 & $2,717,073$ & $2,334,099$ & 382,974 \\
Adj. $R^{2}$ & 0.359 & 0.338 & 0.364 & 0.3926 & 0.3504 & 0.3956 \\
\hline
\end{tabular}

Notes: Standard errors are in parentheses. $* * *$ Significant at the $0.1 \%$ level; ** significant at the $1 \%$ level; * significant at the 5\% level. Additional control variables: Gender (male/female).

Table A3: Effects of the high school reform on apprenticeship contracts by within-occupation share of apprentices with a high school degree

\begin{tabular}{lcccccc}
\hline Dependent variable: & \multicolumn{3}{c}{ West Germany } & \multicolumn{3}{c}{ East Germany } \\
$\begin{array}{l}\ln (\text { apprenticeship } \\
\text { contracts HS degree) }\end{array}$ & $\frac{a_{o, H S}}{a_{o, A L L}}<0.5$ & $0.25<\frac{a_{o, H S}}{a_{o, A L L}}<0.5$ & $\frac{a_{o, H S}}{a_{o, A L L}}>0.5$ & $\frac{a_{o, H S}}{a_{o, A L L}}<0.5$ & $0.25<\frac{a_{o, H S}}{a_{o, A L L}}<0.5$ & $\frac{a_{o, H S}}{a_{o, A L L}}>0.5$ \\
\hline High school reform & $0.056^{* * *}$ & $0.050^{* * *}$ & $0.063^{* * *}$ & $0.163 * * *$ & $0.080^{* *}$ & 0.002 \\
& $(0.016)$ & $(0.016)$ & $(0.018)$ & $(0.039)$ & $(0.035)$ & $(0.043)$ \\
Year dummies & Yes & Yes & Yes & Yes & Yes & Yes \\
Occupational trends & Yes & Yes & Yes & Yes & Yes & Yes \\
State-level trends & Yes & Yes & Yes & Yes & Yes & Yes \\
State and occupation & Yes & Yes & Yes & Yes & Yes & Yes \\
FE & $1.859^{* * *}$ & $2.591 * * *$ & $2.795^{* * *}$ & $1.637 * * *$ & $2.525^{* * *}$ & $2.425^{* *}$ \\
Constant & $(0.033)$ & $(0.037)$ & $(0.033)$ & $(0.050)$ & $(0.049)$ & $(0.056)$ \\
\hline Observations & 11526 & 5960 & 4049 & 4908 & 2960 & 1956 \\
$R^{2}$ & 0.263 & 0.289 & 0.291 & 0.203 & 0.385 & 0.348 \\
\hline Nes
\end{tabular}

Notes: $\frac{a_{o, H S}}{a_{o, A L L}}$ denotes the share of apprentices with a high school degree in training occupation $o$. Standard errors are in parentheses. $* * *$ Significant at the $1 \%$ level; $* *$ significant at the $5 \%$ level; $*$ significant at the $10 \%$ level. 
Table A4: Effects of the high school reform on apprenticeship wages by within-occupation share of apprentices with a high school degree

\begin{tabular}{lcccccc}
\hline Dependent variable: & \multicolumn{3}{c}{ West Germany } & \multicolumn{3}{c}{ East Germany } \\
ln(apprenticeship wages & $\frac{a_{o, H S}}{a_{o, A L L}}<0.5$ & $0.25<\frac{a_{o, H S}}{a_{o, A L L}}<0.5$ & $\frac{a_{o, H S}}{a_{o, A L L}}>0.5$ & $\frac{a_{o, H S}}{a_{o, A L L}}<0.5$ & $0.25<\frac{a_{o, H S}}{a_{o, A L L}}<0.5$ & $\frac{a_{o, H S}}{a_{o, A L L}}>0.5$ \\
\hline HS degree) & 0.000 & 0.007 & 0.006 & -0.026 & 0.018 & -0.011 \\
\hline High school reform & $(0.006)$ & $(0.007)$ & $(0.007)$ & $(0.018)$ & $(0.019)$ & $(0.022)$ \\
& Yes & Yes & Yes & Yes & Yes & Yes \\
Year dummies & Yes & Yes & Yes & Yes & Yes & Yes \\
Occupational trends & Yes & Yes & Yes & Yes & Yes & Yes \\
State-level trends & Yes & Yes & Yes & Yes & Yes & Yes \\
State and occupation FE & $2.940^{* * *}$ & $2.934^{* * *}$ & $2.991 * * *$ & $2.674 * * *$ & $2.735^{* * *}$ & $2.796^{* * *}$ \\
Constant & $(0.016)$ & $(0.012)$ & $(0.012)$ & $(0.023)$ & $(0.018)$ & $(0.025)$ \\
\hline Observations & 3257 & 2098 & 1379 & 1181 & 885 & 519 \\
$R^{2}$ & 0.477 & 0.475 & 0.578 & 0.638 & 0.644 & 0.658 \\
\hline
\end{tabular}

Notes: $\frac{a_{o, H S}}{a_{o, A L L}}$ denotes the within-occupation share of apprentices with a high school degree. Standard errors are in parentheses. $* * *$ Significant at the $1 \%$ level; ** significant at the $5 \%$ level; $*$ significant at the $10 \%$ level.

Table A5: Elasticity of apprenticeship contracts with respect to lower secondary school (LS) graduates: Panel fixed-effects regression

\begin{tabular}{lcccc}
\hline $\begin{array}{l}\text { Dependent variable: } \\
\ln (\text { apprenticeship contracts LS degree) }\end{array}$ & Model 1 & Model 2 & $\begin{array}{c}\text { West } \\
\text { Germany }\end{array}$ & $\begin{array}{c}\text { East } \\
\text { Germany }\end{array}$ \\
\hline $\ln$ (graduates LS) & $0.460^{* * *}$ & $0.470^{* * *}$ & $0.307 * * *$ & 0.160 \\
& $(0.031)$ & $(0.029)$ & $(0.070)$ & $(0.124)$ \\
Year dummies & Yes & Yes & Yes & Yes \\
Occupational trends & No & Yes & Yes & Yes \\
State-level trends & No & Yes & Yes & Yes \\
State and occupation FE & Yes & Yes & Yes & Yes \\
Constant & $-1.577 * * *$ & $-1.701 * * *$ & -0.028 & 1.425 \\
& $(0.320)$ & $(0.298)$ & $(0.730)$ & $(1.206)$ \\
\hline Observations & 30321 & 30321 & 20619 & 9702 \\
$R^{2}$ & 0.090 & 0.235 & 0.232 & 0.327 \\
\hline
\end{tabular}

Notes: Standard errors are in parentheses. $* * *$ Significant at the $1 \%$ level; $* *$ significant at the $5 \%$ level; * significant at the $10 \%$ level. 
Table A6: Elasticity of apprentice wages with respect to lower secondary school graduates: Panel fixed-effects regression

\begin{tabular}{lccccc}
\hline $\begin{array}{l}\text { Dependent variable: } \\
\text { ln(apprentice wage LS } \\
\text { degree) }\end{array}$ & Model 1 & Model 2 & Model 3 & $\begin{array}{c}\text { West } \\
\text { Germany }\end{array}$ & $\begin{array}{c}\text { East } \\
\text { Germany }\end{array}$ \\
\hline ln(graduates LS) & $-0.073 * * *$ & $-0.072 * * *$ & -0.022 & -0.044 & -0.113 \\
& $(0.010)$ & $(0.010)$ & $(0.023)$ & $(0.033)$ & $(0.075)$ \\
Year dummies & Yes & Yes & Yes & Yes & Yes \\
Occupational trends & No & Yes & Yes & Yes & Yes \\
State-level trends & No & No & Yes & Yes & Yes \\
State-level occupation FE & Yes & Yes & Yes & Yes & Yes \\
Constant & $3.489 * * *$ & $3.467 * * *$ & $2.973 * * *$ & $3.279 * * *$ & $3.672 * * *$ \\
& $(0.104)$ & $(0.100)$ & $(0.227)$ & $(0.345)$ & $(0.734)$ \\
\hline Observations & 9916 & 9916 & 9916 & 6717 & 3199 \\
$R^{2}$ & 0.610 & 0.640 & 0.661 & 0.635 & 0.709 \\
\hline N
\end{tabular}

Notes: Standard errors are in parentheses. $* * *$ Significant at the $1 \%$ level; $* *$ significant at the $5 \%$ level; * significant at the $10 \%$ level. 